
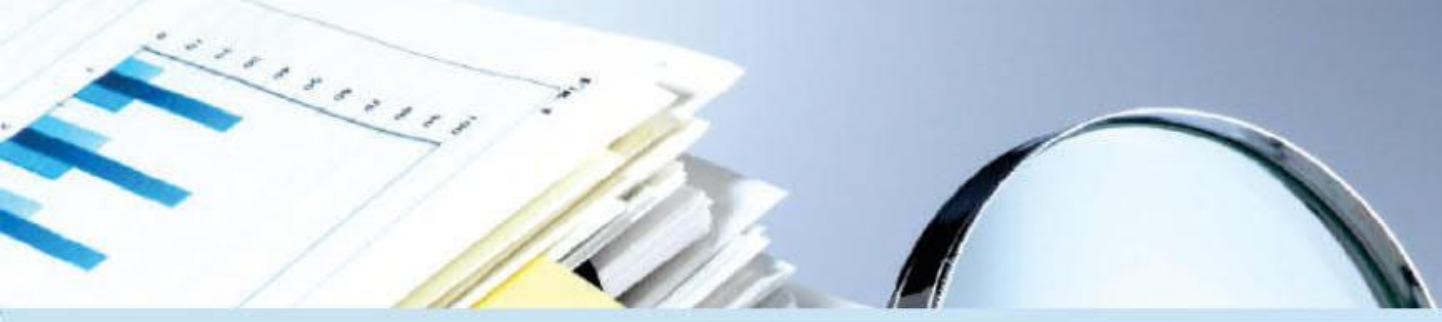

\title{
APLIKASI DAN TEKNIK SURVEY BIDANG KESEHATAN
}

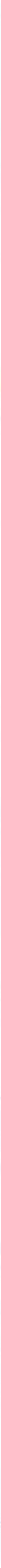




\title{
APLIKASI DAN TEKNIK SURVEY BIDANG KESEHATAN
}

\author{
Dr. Sandu Siyoto, SKM, M.Kes
}

Nia Sari, S.Si, M.Kes 


\section{APLIKASI DAN TEKNIK SURVEY BIDANG KESEHATAN}

$\begin{array}{ll}\text { Penulis } & \text { : Dr. Sandu Siyoto, SKM, M.Kes } \\ & \text { Nia Sari, S.Si, M.Kes } \\ \text { Penyunting } & \text { : Intan } \\ \text { Sampul } & \text { : Febrian } \\ \text { Lay out } & \text { : Faza }\end{array}$

Cetakan I, Agustus 2016

\section{PENERBIT}

\section{Literasi Media}

Karanganyar-Klodangan 004/027 Sendangtirto Berbah Sleman

D.I. Yogyakarta 55573

Phone : +6281555666954

Email : literasimedia01@gmail.com

\section{Perpustakaan Nasional: Katalog Dalam Terbitan (KDT)}

Sandu Siyoto \& Nia Sari, Aplikasi dan Teknik Survey Bidang Kesehatan, Penyunting. Intan -Cetakan 1 - Yogyakarta; Literasi Media, 2016

iv $+64 \mathrm{hlm}, 15 \times 23 \mathrm{~cm}$

ISBN : 978-602-74934-0-7

@All Right Reserved. Hak cipta dilindungi undang-undang No.19 Th. 2002 


\section{KATA PENGANTAR}

Yang pertama dan paling utama tentunya penulis ucapkan syukur segala puji kepada Allah swt, Tuhan semesta alam atas karunia tak terhingga jumlahnya kepada pribadi penulis sehingga buku ini dapat terselesaikan. Shalawat dan salam semoga tetap tercurahkan kepada baginda rasul, Muhammad saw atas jasa-jasanya menerangi bumi dengan iman dan Islam hingga kelak di akhir zaman.

Buku yang berjudul Aplikasi Dan Teknik Survey Bidang Kesehatan ini berfokus pada konsep, teori, dan aplikasi pemilihan sampel pada riset kesehatan. Kehadiran buku diharapkan mampu membantu kesulitan mahasiswa pada saat melakukan pemilihan sampel dalam penelitiannya.

Buku ini terdiri dari 6 bab, dengan deskripsi singkat sebagai berikut.

Bab I membahas pengertian sampel dan sampling, meliputi pengertian sampel, penggunaan sampel, kriteria sampel yang baik, kerangka induk dan kerangka sampel, prinsip kegiatan survey.

Bab II membahas metode sampling meliputi pengertiannya, keuntungan metode dan kelemahan metode sampling.

Bab III membahas metode probabiliti sampling meliputi bahasan simple random sampel, sistematik random sampel, stratified random sampling, multiphase random sampling, probability proporsional to size, multistage random sampling, dan cluster random sampling.

Bab IV membahas metode non probabiliti sampling yang meliputi bahasan convenience sampling, judgement sampling, quota sampling, dan snowball sampling.

Bab V membahas seluk beluk besaran sampel meliputi bahasan bagaimana menentukan ukuran sampel, jenis varians, serta analisis varians

Bab VI membahas seputar teknik survei cepat meliputi bahasan sejarah, karakteristik, langkah-langkah, alasan penggunaaan sampel dalam populasi, besar sample, contoh survei cepat kabupaten, pemilihan sampel dalam klaster, laporan berisi, pengolahan dan analisis data.

Sebagai sebuah karya manusia biasa tentunya buku ini jauh dari kata sempurna. Kritik dan saran penulis sangat diharapkan penulis demi perbaikan buku ini.

Terima kasih tak terhingga penulis sampaikan kepada semua pihak yang tidak bisa disebutkan satu persatu atas bantuan, dorongan, dan dukungan atas terselesaikannya buku ini.

Kediri, Agustus 2016 


\section{DAFTAR ISI}

Kata Pengantar ...........................................................................................................

Daftar Isi.......................................................................................................................... iv

BAB I PENGERTIAN SAMPEL DAN SAMPLING …......................................... 1

Pengertian Sampel $\quad$..........................................

Penggunaan Sampel ...................................... 2

Kriteria Sampel yang Baik ................................................................ 3

Pengertian Sampling............................................................................... 4

Kerangka Induk dan Kerangka Sampel.............................................. $\quad 4$

Prinsip Kegiatan Survei ...................................................................... $\quad 5$

BAB II METODE SAMPLING .................................................................... 6

Pengertian ....................................................................................

Keuntungan Metode Sampling............................................................ $\quad 7$

Kelemahan Metode Sampling............................................................ $\quad 7$

BAB III METODE PROBABILITI SAMPLING................................................ 8

Simple Random Sampel..................................................................... 8

Sistematik Random Sampel.................................................................. 13

Stratified Random sampling .......................................................... $\quad 20$

Cluster Random Sampling ................................................................. 27

Probability Proporsional to Size ........................................................ 27

Multistage Random Sampling ......................................................... $\quad 35$

Multiphase Random Sampling.......................................................... $\quad 37$

BAB IV METODE NON PROBABILITI SAMPLING ......................................... 40

Convenience Sampling ...................................................................... $\quad 40$

Judgement Sampling ......................................................................... 40

Quota Sampling ............................................................................. 41

Snowball Sampling ............................................................................. 42

BAB V BESAR SAMPEL ................................................................................ 43

Menentukan Ukuran Sampel......................................................... 43

Jenis Varians ............................................................................... $\quad 49$

Analisis Varians ................................................................... 51

BAB VI SURVEI CEPAT ……........................................................................... 57

Sejarah ..................................................

Karakteristik .....................................................

Langkah-langkah ...........................................

Alasan Penggunaan Sampel dalam Populasi .............. 58

Besar Sampel .............................................. 58

Contoh Survei Cepat Kabupaten ............................. $\quad 60$

Pemilihan Sampel Dalam Klaster .............................. 61

Pengolahan dan Analisis Data ............................... 62

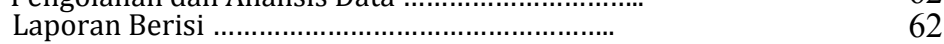

$\begin{array}{lc}\text { DAFTAR PUSTAKA } & 63\end{array}$ 


\section{BAB I \\ PENGERTIAN SAMPEL DAN SAMPLING}

\section{A. PENGERTIAN SAMPEL}

Ketika melakukan penelitian kita sering menyebut istilah populasi dan sample. Agar diperoleh pemahaman yang homogen, secara ringkas kita bahas tentang pengertianpengertian dasar berikut:

Populasi : keseluruhan unit atau individu dengan ciri-ciri yang sama yang ingin diteliti.

Sampel : sebagian anggota dari populasi yang dipilih dengan teknik tertentu dan diharapkan dapat mewakili populasi. Populasi dan Sample memiliki karakteristik yang sama

Parameter : suatu nilai yang menggambarkan karakteristik suatu populasi

Statistik: suatu nilai yang menggambarkan karakteristik suatu sample.

Sensus : suatu pendataan yang dilakukan pada semua individu dalam populasi. Yang diteliti dalam survei adalah populasi (keseluruhan dari unit populasi).

Contoh : Sensus penduduk Indonesia : maka yang dilakukan penelitian adalah seluruh penduduk Indonesia dengan KTP negara Indonesia.

Survei : suatu pendataan yang dilakukan terhadap sample. Yang diteliti dalam survei adalah sampel (sebagian dari unit populasi).

Contoh : Survei penduduk Indonesia : maka yang dilakukan penelitian cukup sebagian penduduk Indonesia dengan KTP negara Indonesia.

Tabel 1. Perbedaan antara Statistik Sampel dengan Parameter Populasi

\begin{tabular}{|l|l|l|}
\hline Ukuran/Ciri & $\begin{array}{l}\text { Parameter } \\
\text { (Indikator Populasi) }\end{array}$ & $\begin{array}{l}\text { Statistik } \\
\text { (Indikator Sampel) }\end{array}$ \\
\hline Jumlah & $\mathrm{N}$ & $\mathrm{N}$ \\
\hline Rata-Rata & $\mu$ & $\bar{x}$ \\
\hline Selisih 2 Rata-rata & $\left|\mu_{1}-\mu_{2}\right|$ & $\left|\bar{x}_{1}-\bar{x}_{2}\right|$ \\
\hline $\begin{array}{l}\text { Standar Deviasi } \\
\text { (Simpangan Baku) }\end{array}$ & $\sigma$ & $\mathrm{S}$ \\
\hline Varians (Ragam) & $\sigma^{2}$ & $\mathrm{~s}^{2}$ \\
\hline Proporsi & $\pi$ & $\bar{p}$ atau $\hat{p}$ \\
\hline Selisih 2 proporsi & $\left|\pi_{1}-\pi_{2}\right|$ & $\left|p_{1}-p_{2}\right|$ \\
\hline Korelasi & \multicolumn{1}{|c|}{$\rho$} & $\mathrm{R}$ \\
\hline
\end{tabular}




\section{B. PENGGUNAAN SAMPEL}

Ketika melakukan penelitian, maka yang menjadi dasar pertimbangan dalam penggunaan sample sebagai berikut:

1. Sebagai peneliti, dalam penelitian kita tidak mungkin mengamati semua anggota populasi.

2. Menghemat waktu, biaya dan tenaga peneliti

3. Populasi akan menjadi rusak atau habis jika disensus. Sebagai contoh kita ingin mengetahui rasa es cream yang ingin kita jual. Ketika kita mencicipi semua es cream, maka es cream tadi tidak akan bisa kita jual karena akan habis kita cicipi semua.

4. Mampu memberikan informasi yang lebih menyeluruh dan mendalam secara cepat (Akurasi lebih tinggi)

\section{KRITERIA SAMPEL YANG BAIK}

Sample yang tepat adalah sampel yang mewakili seluruh anggota populasi (representatif) dan mampu memberikan informasi yang terkait dengan populasi yang diteliti. Informasi tersebut dapat digunakan sebagai bahan dalam pengambilan keputusan. Agar informasi yang diperoleh dapat memenuhi tujuan maka dibutuhkan ketepatan data yang dikumpulkan.

Syarat sample yang baik, yaitu:

1. Obyektif (sesuai dengan kenyataan yang sebenarnya)

2. Representatif (mewakili keadaan yang sebenarnya)

3. Memiliki variasi yang kecil

4. Tepat Waktu dan Relevan

5. Kebenaran yang dapat diukur

Estimasi yang berasal dari sampel harus dapat diukur tingkat kebenarannya yang berupa perkiraan total, rata-rata, dsb, dengan menyajikan besarnya kesalahan sampling serta selang kepercayaannya. Pengukuran tingkat ketelitian ini disesuaikan dengan metode sampling yang digunakan. Diharapkan hasil penghitungan kesalahan sampling antara rencana dan realisasi tidak terlalu jauh berbeda.

Sampel yang representatif adalah sampel yang mewakili populasu yang ingin diteliti. Untuk menentukan sampel yang representatif ada beberapa faktor yang harus dipertimbangkan, yaitu:

1. Derajat keseragaman (degree of homogenity) populasi.

Populasi homogen cenderung memudahkan penarikan sampel, sampai pada menentukan besar kecil sampel yang dibutuhkan. Semakin homogen populasi, maka semakin besar kemungkinan penggunaan sampel dalam jumlah kecil. Pada populasi heterogen, kecenderungan menggunakan sampel, besar kemungkinan sulit dihindari, karena sampel harus dipenuhi oleh wakil-wakil unit populasi. Oleh karena itu, semakin 
kompleks atau semakin tinggi derajat keberagaman maka semakin besar pula sampel penelitian yang diperoleh.

2. Derajat kemampuan peneliti mengenai sifat-sifat khusus populasi.

Selain mengenal derajat keberagaman populasi, peneliti juga harus mampu mengenal ciri-ciri khusus populasi yang sedang atau akan diteliti.

3. Presisi (keseksamaan) yang dikehendaki penelitian.

Faktor ketiga ini biasanya merupakan kebutuhan yang muncul pada penelitian survei atau penelitian kuantitatif lainnya. Populasi penelitian amat besar, sehingga derajat kemampuan peneliti dalam mengenal karakteristik populasi amat rendah. Untuk menghindari kebiasan sampel, maka dilakukan jalan pintas dengan cara menambah ukuran sampel. Oleh karenanya, apabila suatu penelitian menghendaki derajat presisis yang tinggi,maka merupakan keharusan dari penelitian tersebut menggunakan menggunakan sampel dengan ukuran yang besar, karena derajat presisi menentukan besar kecilnya ukuran sampel. Pada permasalahan ini, presisi juga tergantung pada tenaga, biaya, dan waktu, karena untuk mencapai derajat presisi tinggi, peneliti harus mengeluarkan banyak tenaga, biaya maupun waktu untuk melayani sampel dengan ukuran yang besar.

4. Penggunaan teknik sampling yang tepat.

Penggunaan teknik sampling juga harus betul-betul diperhatikan kalau mau mendapatkan sampel yang representatif. Salah dalam penggunaan teknik sampling, berarti salah pula dalam memperoleh sampel.

Untuk mencapai tujuan tersebut diperlukan metode pengambilan sample yang tepat agar sample yang diambil dapat diperoleh statistik yang dapat digunakan sebagai penduga bagi parameter populasi. Sedangkan statistik yang diperoleh akan menjadi penduga yang baik jika memenuhi syarat berikut:

1. Unbiased

Suatu penduga dikatakan unbiased apabila nilai yang diharapkan sama dengan nilai parameter atau dilambangkan dengan $E(\theta)=\theta$.

\section{Efisien}

Suatu penduga dikatakan efisien apabila penduga tersebut memiliki standard error yang terkecil dibandingkan dengan standard error penduga yang lain.

3. Konsisten

Suatu penduga dikatakan konsisten apabila peluang untuk memperoleh perbedaan antara statistik dengan parameter mendekati nol jika jumlah sample bertambah. Artinya jika sample diperbesar maka suatu nilai satstistik akan semakin mendekati nilai parameter yang diestimasi. 


\section{PENGERTIAN SAMPLING}

Dalam Sampling ada beberapa istilah yang sering digunakan sebagai berikut:

Unit : unit yang digunakan untuk mendapatkan informasi.

Unit Observasi : unit dimana informasi diperoleh baik secara langsung maupun tidak langsung.

Unit Sampling : unit yang dijadikan dasar dalam penarikan sample

Daftar Unit : Daftar unit adalah daftar yang digunakan untuk dasar penarikan sampel seperti direktori perusahaan/usaha atau daftar rumah tangga dalam blok sensus.

Kerangka Sampel: Indikator dalam populasi yang dijadikan dasar dalam penarikan sample.

\section{E. KERANGKA INDUK DAN KERANGKA SAMPEL}

Ketika melakukan survey perlu dipertimbangkan berbagai variabel yang akan dicakup, baik sifat-sifat variabel maupun kemungkinan adanya non-respon seperti menolak, tidak mampu menjawab, tidak ditemui, dsb.

Langkah selanjutnya adalah meneliti kemungkinan populasi kerangka induk yang sesuai dan kemungkinan penggunaannya.

1. Kerangka Induk

Kerangka induk (master frame) merupakan kerangka dasar yang harus menjadi perhatian utama sebelum penentuan desain sampling dan pembentukan kerangka sampel induk (master sampling frame). Penyediaan kerangka induk cukup mahal, tapi tanpa kerangka induk yang baik tidak mungkin dibentuk kerangka sampel.

Persyaratan :

Kerangka sampel induk yang dibentuk dari kerangka induk harus dapat digunakan untuk penerapan penarikan sampel dengan peluang. Persyaratan kerangka sampel induk adalah sebagai berikut :

- Tersedia sampai satuan unit terkecil yang digunakan sebagai dasar penarikan sampel.

- Mempunyai batasan yang jelas.

- Tidak saling tumpang tindih atau terlewat.

- Mempunyai korelasi dengan dat yang akan diteliti.

- Up to date (mutakhir)

\section{Persyaratan tersebut sangat diperlukan agar tidak terjadi :}

- Unit sampel yang tidak dijumpai

- Unit sampel yang duplikasi

- Unit sampel yang terpecah

- Unit sampel yang tergabung

- Unit baru 


\section{Bias Effect :}

Bila listing tidak benar, maka estimasi juga tidak akan mewakili populasi. Oleh karena itu, pelaksanaan listing perlu mendapat perhatian. Listing merupakan bagian dari kerangka sampel induk yang dibentuk dilapangan bersamaan dengan pelaksanaan survey. Bila data listing tidak akurat akan menjadikan bias yang disebabkan kerangka sampel cukup besar.

2. Jenis Kerangka sampel

Kerangka sampel yang dapat dibentuk dapat dikategorikan sebagai berikut :

- Dalam bentuk daftar individu

Daftar Individu langsung dapat digunakan sebagai dasar penarikan sampel seperti daftar nama calon sampel, daftar Puskesmas, daftar RS, daftar Sekolah, dst.

Kerangka yang berupa individu lebih labil dan cepat berubah. Karena itu Individu sebagai kerangka induk perlu ditentukan dengan jelas batasannya.

- Dalam bentuk daftar wilayah

Daftar dalam bentuk wilayah seperti halnya blok harus dilengkapi dengan peta supaya memudahkan dalam melakukan penarikan sampel.

Contoh dalam bentuk daftar wilayah adalah RT, Kelurahan, Kota dst.

Kerangka sampel yang berupa wilayah pembentukannya tentunya sudah memenuhi persyaratan batas yang jelas sehingga dapat dipertahankan dalam kurun waktu yang cukup lama.

\section{F. PRINSIP KEGIATAN SURVEI}

Dalam kegiatan survei perlu diperhatikan beberapa hal, sebagai berikut:

1. Obyek dan tujuan dari survey

2. Populasi dari survey

3. Data yang akan dikumpulkan

4. Tingkat ketelitian yang dikehendaki

5. Kerangka Sampel dan cara penarikan sample

6. Target populasi yang disajikan (estimasi)

7. Inferensial yang berupa kajian dan analisis 


\section{BAB II \\ METODE SAMPLING}

\section{A. PENGERTIAN}

Sampling adalah pengambilan sampel dari populasi. Sedangkan Metode Sampling adalah metode atau teknik untuk memilih dan mengambil sampel dari populasi secara benar. Jika pemilihan dan pengambilannya dilakukan secara benar, maka bisa kita katakan bahwa sampel kita bisa digunakan untuk mewakili populasi (Sampel yang reprresentative). Metode sampling dalam penerapannya digunakan untuk menyajikan data yang mewakili populasi ditinjau dari keefisienannya dan hematnya biaya. Informasi yang dihasilkan dapat disajikan dan dianalisis secara statistik dan harus mempunyai tingkat ketelitian tertentu (precise) yang dapat diukur.

Metode sampling yang sering digunakan ada dua macam, yaitu Probability Sampling dan Non Probability Sampling.

1. Probability Sampling

Probability Sampling adalah metode pemilihan sample dari suatu populasi dengan menggunakan kaidah-kaidah probabilita.

Dalam probability sampling, pemilihan sample tidak dilakukan secara subyektif, dalam arti sample yang terpilih tidak didasarkan pada keinginan peneliti, sehingga setiap anggota populasi memiliki kesempatan yang sama untuk terpilih sebagai sample. Dengan demikian diharapkan sample yang terpilih dapat digunakan untuk menduga karakteristik populasi secara obyektif.

Contoh : Simple Random Sampling, Sistematik sampling, Stratified Random Sampling, Cluster Random Sampling, Multistage Random Sampling, dst.

2. Non Probability Sampling

Non Probability Sampling adalah metode pemilihan sample dari suatu populasi tidak menggunakan kaidah-kaidah probabilita.

Metode Non Probability Sampling digunakan apabila metode Probability Sampling tidak dapat digunakan terutama dalam kaitannya dengan pengurangan biaya, waktu, tenaga dan permasalahan yang timbul dalam pembuatan kerangka sample.

Contoh : Convinience Sampling, Judgement Sampling, Quota Sampling, Snowball Sampling, dst 


\section{B. KEUNTUNGAN METODE SAMPLING}

Keuntungan menggunakan metode sampling, antara lain:

1. Menghemat Biaya

Menghemat Biaya karena data yang dikumpulkan hanya sebagian dari populasi. Karena merupakan sample, maka petugas yang dibutuhkan lebih sedikit, hemat biaya percetakan, biaya pelatihan, pencacahan, dan pengolahan.

2. Mempercepat Hasil Survei

Pada umumya data yang dibutuhkan segera, sehingga berbagai perencanaan segera dapat dilakukan. Dengan melakukan survei sample maka pelaksanaan lapangan dan pengolahan tentunya akan jauh lebih cepat diselesaikan.

3. Cakupan Materi Lebih Besar

Data yang diperlukan biasanya beragam dan cukup banyak, sehingga tidak mungkin dikumpulkan melalui pencacahan lengkap. Data yang dikumpulkan melalui sensus lengkap biasanya sangat terbatas. Variable yang dicakup sangat dibatasi pada variable dasar saja.

4. Akurasi Lebih Tinggi

Pada sensus jumlah petugas dan responden yang besar akan mengakibatkan tingkat kesalahan yang juga besar terutama kesalahan yang diakibatkan bukan oleh teknik sampling yang disebut dengan Non Sampling Error. Non Sampling Error dapat diakibatkan oleh tidak terpenuhi kualifikasi petugas yang baik, kuesioner yang kurang baik, konsep dan definisi yang kurang tepat, jawaban responden yang salah, maupun kesalahan dalam proses pengolahan.

\section{KELEMAHAN METODE SAMPLING}

Kelemahan menggunakan metode sampling, antara lain:

\section{Penyajian Wilayah Kecil}

Penyajian wilayah kecil seperti kecamatan dan desa dengan sample terbatas tidak dapat dipenuhi. Pada umumnya jumlah sample yang digunakan sesuai dengan tingkat ketelitian yang dikehendaki.

\section{Penyajian Variable Proporsi Kecil}

Survei sample tidak dapat menyajikan variable yang kejadiannya kecil dalam populasi (proporsi kecil).

\section{Trend Data}

Apabila data diperlukan secara berkala untuk mengukur perubahan yang sangat kecil dari satu period ke periode berikutnya, kemungkinan sample diperlukan cukup besar.

\section{Tidak Tersedianya Kerangka Sampel}

Tidak tersedianya kerangka sample sehingga persyaratan probabilita sampling tidak terpenuhi. Biaya untuk pembentukan kerangka sample cukup tinggi sehingga memiliki pengaruh besar terhadap total biaya. 


\section{BAB III \\ METODE PROBABILITY SAMPLING}

\section{A. SIMPEL RANDOM SAMPLING/SAMPEL ACAK SEDERHANA (SAS)}

Penarikan sampel acak sederhana (SAS) ialah suatu penarikan sampel yang dilakukan terhadap elemen-elemen didalam populasi yang telah didefinisikan. Unit penarikan sampelnya berupa unit-unit yang terdaftar dalam kerangka sampel itu sendiri. Oleh karena itu SAS adalah suatu prosedur penarikan sampel yang paling sederhana. Prosedur-prosedur penarikan sampel dapat dipandang sebagai suatu modifikasi atau pengembangan dari SAS, yang dimaksudkan untuk menyesuaikan dengan kondisi dan situasi nyata yang dihadapi ketika melakukan penarikan sampel terhadap suatu populasi tersebut. Modifikasi dan pengembangan dapat dipertimbangkan karena adanya persyaratan yang tidak dapat dipenuhi dalam mengoperasikan SAS atau didasarkan atas satu atau beberapa tujuan lain. Misalnya, yang berhubungan dengan alasan kepraktisan atau keterlaksanan, biaya, tersedianya beberapa tambahan keterangan tentang unit dalam populasi dan untuk memperoleh dugaan yang lebih teliti dan tepat.

Penarikan Sampel Acak Sederhana (SAS) pada umumnya digunakan bila kita dihadapkan pada situasi-situasi :

1. Sangat terbatasnya pengetahuan terhadap unsur-unsur populasi.

Keterangan sebelumnya yang lebih rinci dan diperlukan untuk menilai derajat keseragaman atau untuk mengolong-golongkan unsur-unsur populasi tidak diperoleh.

2. Dari pengetahuan yang ada atau pengalaman selama ini, belum diperoleh suatu prosedur seleksi tandingan yang lebih efisien daripada SAS.

Beberapa syarat yang perlu dipenuhi dalam mempergunakan Sampel Acak Sederhana (SAS) ialah:

1. Tersedianya daftar kerangka sampel yang cermat dan lengkap, mencakup seluruh elemen populasi.

Jika kerangka sampel yang memuat elemen-elemen yang dimaksudkan belum tersedia, maka harus dibuat lebih dahulu sebelum penarikan sampel dapat dilakukan.

2. Untuk variabel-variabel tertentu yang akan diamati, populasi data dapat dianggap bersifat cukup seragam. Penyimpangan yang besar terhadap anggapan ini akan memperbesar kemungkinan terjadinya bias akibat penarikan sampel. 
3. Dalam praktek, penarikan sampel yang (langsung atau tak langsung) jika dilihat dari geografis atau sebaran elemen-elemen populasi tidak terlalu terpencar-pencar dalam areal yang luas.

Ada 2 cara dalam seleksi unsur-unsur untuk suatu sampel Penarikan Sampel Acak Sederhana (SAS)

1. Seleksi elemen dengan Pemulihan (Without replacement)

All posible sample $=\mathrm{N}^{\mathrm{n}}$

Yang dimaksud seleksi dengan pemulihan adalah setiap sampel hanya memiliki probabilitas terambil satu kali.

2. Seleksi elemen tanpa pemulihan (With replacement)

All posible sample $={ }^{\mathrm{N}} \mathrm{C}_{\mathrm{n}}$

Yang dimaksud seleksi tanpa pemulihan adalah setiap sampel memiliki probabilitass terambil lebih dari satu kali.

Jika varians populasi dan sampel dituliskan dalam rumus berikut :

$$
\begin{aligned}
& \sigma^{2}=\frac{1}{N} \sum_{i=1}^{N}(Y i-\bar{Y})^{2} \\
& S^{2}=\frac{1}{N-1} \sum_{i=1}^{N}(Y i-\bar{Y})^{2}
\end{aligned}
$$

Dan Rata-Rata didapatkan dengan :

$$
\bar{y}=\frac{1}{n} \sum_{i=1}^{n} y i
$$

Sedangkan Estimasi dari varian bagi $\bar{Y}$

$$
V(\bar{y})=\frac{N-n}{N} \frac{S^{2}}{n} \quad \text {; Seleksi dengan pemulihan }
$$

Dan

$$
=\frac{\sigma^{2}}{n} \quad \text {; jika Seleksi tanpa pemulihan }
$$

$E\left(s^{2}\right)=S^{2} \quad ;$ Seleksi dengan pemulihan

$\mathrm{E}\left(\mathrm{s}^{2}\right)=\sigma^{2} \quad$; jika Seleksi tanpa pemulihan

$v(\bar{y})=\frac{N-n}{N} \frac{s^{2}}{n} \quad$; Seleksi dengan pemulihan

$=\frac{s^{2}}{n} \quad$; jika Seleksi tanpa pemulihan 


$$
\begin{aligned}
& \operatorname{Se}(\bar{y})=\sqrt{v(\bar{y})} \\
& \operatorname{RSE}=\frac{\operatorname{Se}(\bar{y})}{\bar{y}} \times 100 \%
\end{aligned}
$$

Nilai Relative Standart Error (RSE) :

$$
\begin{array}{ll}
\operatorname{RSE}(\bar{y})=\frac{1}{\sqrt{n}} \frac{s}{\bar{y}} & ; \text { Seleksi tanpa pemulihan (WR) } \\
=\frac{1}{\sqrt{n}} \frac{s}{y} \frac{\sqrt{N-n}}{\sqrt{N}} & ; \text { Seleksi dengan pemulihan (WOR) }
\end{array}
$$

Untuk Selang Kepercayaan (Confidence Interval) didapatkan dari :

$$
\bar{y}-Z_{\alpha / 2} s_{-}<\bar{Y}<\bar{y}+Z_{\alpha / 2} s_{-}
$$

Dan rumus untuk ukuran Sampel, jika :

$$
d-Z_{\alpha / 2} s_{\bar{y}}
$$

With Replacement ; $\mathrm{n}=\frac{Z^{2} \alpha / 2 s^{2}}{d^{2}} \quad$ dan

Without Replacement $\quad ; \mathrm{n}=\frac{N Z^{2} \alpha / 2 s^{2}}{N d^{2}+Z^{2} \alpha / 2 s^{2}}$

Estimasi Total Populasi : $\hat{Y}=\mathrm{N} \bar{Y}$

$$
\begin{array}{ll}
Y=\sum_{i=1}^{N} Y i & \\
\bar{Y}=\frac{1}{N} \sum_{i=1}^{N} Y i & \\
\hat{Y}=N \bar{y} \quad \text { dengan } \quad \bar{y}=\frac{1}{n} \sum_{i=1}^{n} y i
\end{array}
$$

Varian dari $\hat{Y}$

$$
\begin{aligned}
V(\hat{Y}) & =N^{2} \frac{N-n}{N} \frac{S^{2}}{n} & & ; \text { Without replacement } \\
& =N^{2} \frac{N-1}{N} \frac{S^{2}}{n}=N^{2} \frac{S^{2}}{n} & & ; \text { With replacement } \\
v(\hat{Y}) & =N^{2} \frac{N-n}{N} \frac{s^{2}}{n} & & ; \text { Without replacement } \\
& =N^{2} \frac{s^{2}}{n} & & ; \text { With replacement }
\end{aligned}
$$


$\operatorname{Se}(\hat{Y})=\operatorname{NSe}(\bar{y})$

Nilai Relative Standart Error

$$
\begin{aligned}
\operatorname{RSE}(\hat{Y}) & =\frac{N}{\sqrt{n}} \frac{s}{Y}=\frac{1}{\sqrt{n}} \frac{s}{y} & & \text {; With replacement } \\
& =\frac{N}{\sqrt{n}} \frac{s}{Y} \frac{\sqrt{N-n}}{\sqrt{N}}=\frac{1}{\sqrt{n}} \frac{s}{y} \frac{\sqrt{N-n}}{\sqrt{N}} & & \text {; Without replacement }
\end{aligned}
$$

Confidence Interval

$$
\text { With replacement } \quad \hat{Y}-Z_{\alpha / 2} s_{y}<Y<\hat{Y}+Z_{\alpha / 2} s_{y}
$$

Ukuran Sampel

$$
\begin{array}{r}
d=Z_{\alpha / 2} s_{y} \\
; \mathrm{n}=\left(\frac{Z_{\alpha / 2} N s}{d}\right)^{2}
\end{array}
$$

Without replacement $\quad ; \mathrm{n}=\frac{N Z^{2} \alpha / 2 s^{2}}{d^{2}+N Z^{2} \alpha / 2 s^{2}}$

\section{Estimasi Proporsi}

$$
\begin{array}{ll}
\bar{X}=\frac{1}{N} \sum_{i=1}^{N} X i \quad, \quad \mathrm{Xi}=0,1 \quad, \quad \hat{X}=N P \\
P=\frac{1}{n} \sum_{i=1}^{N} X i=\frac{X}{N} & \mathrm{Xi}=0,1 \\
p=\frac{1}{n} \sum_{i=1}^{n} x i=\frac{x}{n} &
\end{array}
$$

Varian dari Proporsi

$$
\begin{array}{rlr}
V(P)=\frac{N-n}{N-1} \frac{P Q}{n} & ; \text { Without replacement } \\
& =\frac{N-1}{N} \frac{P Q}{n}=\frac{P Q}{n} & ; \text { With replacement }
\end{array}
$$




$$
\begin{array}{rlr}
v(p)= & \frac{N-n}{N} \frac{p q}{n-1} & ; \text { Without replacement } \\
& =\frac{N-1}{N} \frac{p q}{n-1}=\frac{p q}{n-1} & ; \text { With replacement }
\end{array}
$$

$S e=\sqrt{v(p)}$

Nilai Relative Standart Error (RSE) :

$$
\begin{aligned}
\operatorname{RSE}(P) & =\frac{1}{\sqrt{n}} \frac{\sqrt{q}}{\sqrt{p}} \\
& =\frac{1}{\sqrt{n}} \frac{\sqrt{q}}{\sqrt{p}} \frac{\sqrt{N-n}}{\sqrt{N}}
\end{aligned}
$$

Confidence Interval

$$
p-Z_{\alpha / 2} s_{p}<P<p+Z_{\alpha / 2} s_{p}
$$

Ukuran sampel

$$
d=Z_{\alpha / 2} s_{p}
$$

With replacement $\quad ; \mathrm{n}=\frac{Z^{2} \alpha / 2 p q+1}{d^{2}}$

Without replacement $\quad ; \mathrm{n}=\frac{N Z^{2} \alpha / 2 p q}{N d^{2}+Z^{2} \alpha / 2 p q}$

\section{Example :}

Sebuah sampel yang terdiri dari 100 rumah tangga (RT) dipilih dari populasi yang terdiri dari 2000 rumah tangga dengan teknik Simple Random Sampling Without Replacement. Dari sampel diketahui bahwa 15 RT positif jentik dengan jumlah anggota RT masing-masing $8,7,3,3,5,4,3,4,5,6,6,5,4,3,2$.

a. Dugalah total RT yang positif jentik dan nilai Relative Standart Error (RSE) nya

b. Dugalah total penduduk diwilayah tersebut dengan RSE-nya

\section{Jawab}

Diketahui : $\mathrm{N}=2000$

$$
\begin{aligned}
& \mathrm{n}=100 \\
& \mathrm{x}=15
\end{aligned}
$$

a) $p=\frac{x}{n}=\frac{15}{100}=0,15$ 


$$
\begin{aligned}
& \hat{X}=N p=2000 \times 0,15=300 \\
& R S E(\hat{X})=\frac{1}{\sqrt{n}} \frac{\sqrt{p}}{\sqrt{q}} \frac{\sqrt{N-n}}{\sqrt{N}}=\frac{1}{\sqrt{100}} \frac{\sqrt{0,85}}{\sqrt{0,15}} \frac{\sqrt{1900}}{\sqrt{2000}}=0,232
\end{aligned}
$$

Jadi, diduga ada 300 Rumah Tangga yang positif jentik dengan nilai RSE 0,232

b) Diketahui : $\bar{x}=\frac{2000}{300}=4,5333$

$$
\begin{aligned}
& \mathrm{s}=1,6847 \\
& \hat{X}=\mathrm{N} \bar{x}=2000 \times 4,5333=9066,60 \approx 9067
\end{aligned}
$$

$$
R S E(\hat{X})=\frac{1}{\sqrt{n}} \frac{s}{y} \frac{\sqrt{N-n}}{\sqrt{N}}=\frac{1}{\sqrt{15}} \frac{1,6847}{4,5333} \frac{\sqrt{1985}}{\sqrt{2000}}=0.0956
$$

Jadi, diduga jumlah penduduk sebesar 9067 dengan nilai RSE 0,232

\section{B. SISTEMATIK RANDOM SAMPLING (SRS)}

Pada penarikan sampel acak sederhana (SAS) setiap unit dipilih dengan menggunakan tabel angka random. Cara ini agak berat dalam mengerjakannya karena angka random yang diambil harus sebanyak $\mathrm{n}$ yang memenuhi syarat angka random. Penarikan sampel secara sistematik akan membantu mempermudah penarikan sampel dengan hanya menggunakan satu angka random yang memenuhi persyaratan sedangkan angka random berikutnya akan mengikuti dengan menghitung intervalnya $(\mathrm{k})=k=\frac{N}{n}$. Jadi dalam Sistematik Random Sampling (SRS) pengambilan pertama saja yang dilakukan secara acak dengan menggunakan bilangan random, sedangkan pengambilan selanjutnya dengan menggunakan pengambilan berdasarkan interval.

\section{Keuntungan Sampling Sistematik :}

1. Apabila setiap unit atau elemen dari populasi menyebar secara merata di seluruh populasi dalam keadaan ini sering menghasilkan kesalahan sampling yang lebih kecil. Bila unit/elemen mernyebar secara sembarang bisanya sampling sistematik sama efesien dengan acak sederhana.

2. Memungkinkan diadakan pengaturan letak unit sampling menurut karakteristik sehingga diharapkan sampel memiliki berbagai karakteristik.

\section{Kelemahan Sampling Sistematik :}

Kelemahan dalam sistematik akan terjadi bila unit dalam populasi yang akan diambil sampel mengikuti suatu pola tertentu misalnya berfluktuasi secara periodik sehingga mengakibatkan: 
1. Unit sampel tertentu saja yang terambil sampel

2. Bila interval terlalu besar, maka suatu karakteristik dengan proporsi yang lebih kecil dari fraksi $\left(\frac{n}{N}\right)$ tidak akan terpilih dalam sampel

\section{Cara Penarikan Sampel dalam SRS}

1. Metode A : Sistematik linier (Linier Systematic)

Jika $\mathrm{R}_{1}$ (angka random pertama) $\leq \mathrm{k}$ (interval)

$\mathrm{R}_{2}=\mathrm{R}_{1}+\mathrm{K} ; \mathrm{R}_{3}=\mathrm{R}_{1}+2 \mathrm{k}$; dst

$\mathrm{R}_{\mathrm{n}}=\mathrm{R}_{1}+(\mathrm{n}-1) \mathrm{k}$

$\mathrm{R}_{\mathrm{n}}$ : angka random selanjutnya

Misal: $\quad \mathrm{N}=20, \mathrm{n}=4$

$k=\frac{N}{n}=\frac{20}{4}=5$

$\mathrm{R}_{1} \leq 5=3$

Maka nomor unit-unit terpilih : 3, 8, 13, 18

$\mathrm{R}_{\mathrm{n}}=\mathrm{R}_{4}=3+3(5)=18$

2. Metode B : Sistematik Sirkuler (Circular Systematic)

Jika $\mathrm{R}_{1}$ (angka random pertama) $\leq \mathrm{N}$

$$
\begin{aligned}
& \mathrm{R}_{2}=\mathrm{R}_{1}+\mathrm{K} ; \mathrm{R}_{3}=\mathrm{R}_{1}+2 \mathrm{k} ; \mathrm{dst} \\
& \mathrm{R}_{\mathrm{m}}=\mathrm{R}_{1}+(\mathrm{m}-1) \mathrm{k}
\end{aligned}
$$

$\mathrm{R}_{\mathrm{n}}=\mathrm{R}_{1}+(\mathrm{n}-1) \mathrm{k}$

$\mathrm{Rm}$ : perhitungan angka random terakhir sebelum nomor urut terakhir

Jika $\mathrm{Rm}>\mathrm{N}$, maka Rm menadi Rm' $=\mathrm{Rm}-\mathrm{N}$

Misal: $\quad \mathrm{N}=20$

$$
\mathrm{n}=4
$$

$k=\frac{N}{n}=\frac{20}{4}=5$

$\mathrm{R}_{1} \leq \mathrm{N}=12$

Maka nomor urut terpilih : 12, 17. 2,7

$\mathrm{R}_{1} \quad=12$

$\mathrm{R}_{2}=12+5=17$

$\mathrm{R}_{3}=17+5-20=2$

$\mathrm{R}_{4}=2+5=7==>\mathrm{R}_{\mathrm{n}}=\mathrm{R}_{1}+(\mathrm{n}-1) \mathrm{k}$

$$
=12+3.5=27-20=7
$$

Peluang unit dalam populasi terpilih menjadi sampel

\begin{tabular}{|l|l|l|}
\hline Metode & $\mathbf{N}=\mathbf{n k}$ & $\mathbf{N} \neq \mathbf{n k}$ \\
\hline $\mathrm{A}$ & $1 / \mathrm{k}$ & $1 / \mathrm{k}$ \\
$\mathrm{B}$ & $1 / \mathrm{k}$ & $\mathrm{n} / \mathrm{N}$ \\
\hline
\end{tabular}




\section{Estimasi Rata-Rata Populasi}

\begin{tabular}{|l|l|l|}
\hline Metode & $\mathbf{N}=\mathbf{n k}$ & $\mathbf{N} \neq \mathbf{n k}$ \\
\hline A & Unbiased & Biased \\
B & Unbiased & Unbiased \\
\hline
\end{tabular}

1. Metode A

a. $\mathrm{N}=\mathrm{nk}$

Misalnya, jika populasi : 6, 3, 4, 9, 2, 5, 1, 7, 8, dan $N=9$ serta $K=3$, maka $n=\frac{N}{k}=\frac{9}{3}=3$

\begin{tabular}{|l|l|l|}
\hline Sampel \# 1 & Sampel \# 2 & Sampel \# 3 \\
\hline 6 & 3 & 4 \\
9 & 2 & 5 \\
1 & 7 & 8 \\
\hline 16 & 12 & 17 \\
\hline
\end{tabular}

$\bar{x}_{1}=\frac{16}{3} \quad \bar{x}_{2}=\frac{12}{3} \quad \bar{x}_{3}=\frac{17}{3}$

\# : Kemungkinan sampel terpilih

$E\left(X_{s y}\right)=\frac{1}{3}\left(\frac{16}{3}+\frac{12}{3}+\frac{17}{3}\right)=\frac{45}{9}=5$

$\bar{x}=\frac{1}{9}(6+3+4+9+2+5+1+7+8)=\frac{1}{9}(45)=5$

Jadi $E\left(\bar{x}_{s y}\right)=\bar{X}$ (unbiased)

b. $\mathrm{N} \neq \mathrm{nK}$

Misalnya, jika populasi : 6, 3 , 4, 9, 2, 5, 1, 7 dan $\mathrm{N}=8$

\begin{tabular}{|l|l|l|}
\hline Sampel \# 1 & Sampel \# 2 & Sampel \# 3 \\
\hline 6 & 3 & 4 \\
9 & 2 & 5 \\
1 & 7 & - \\
\hline 16 & 12 & 9 \\
\hline
\end{tabular}

$$
\begin{aligned}
& \bar{x}_{1}=\frac{16}{3} \quad \bar{x}_{2}=\frac{12}{3} \quad \bar{x}_{3}=\frac{9}{2} \\
& E\left(X_{s y}\right)=\frac{1}{3}\left(\frac{16}{3}+\frac{12}{3}+\frac{9}{2}\right)=4,6111
\end{aligned}
$$


$\bar{x}=\frac{1}{8}(6+3+4+9+2+5+1+7)=\frac{37}{9}=4,625$

Jadi $E\left(\bar{x}_{s y}\right) \neq \bar{X}$ (biased)

\section{Metode B}

\section{a. $\mathrm{N}=\mathrm{nK}$}

Caranya sama dengan metode $\mathrm{A}$ dengan $\mathrm{N}=\mathrm{nK}$

Kesimpulan: $E\left(\bar{x}_{s y}\right)=\bar{X}$ (unbiased)

b. $\mathrm{N} \neq \mathrm{nK}$

Misalnya, jika populasi : 6, 3, 4, 9, 2, 5, 1, 7 dan $\mathrm{N}=8$ serta $\mathrm{k}=3$ kemudian $\mathrm{R} 1$ adalah unit ke-7, maka :

$\frac{R_{1}}{k}=\frac{7}{3}=2 \quad$ dengan sisa $(\mathrm{r})=1$

\begin{tabular}{|l|l|l|}
\hline Sampel \# 1 & Sampel \# 2 & Sampel \# 3 \\
\hline 6 & 3 & 4 \\
9 & 2 & 5 \\
1 & 7 & - \\
\hline 16 & 12 & 9 \\
\hline
\end{tabular}

$\bar{x}_{1}=\frac{16}{3} \quad \bar{x}_{2}=\frac{12}{3} \quad \bar{x}_{3}=\frac{9}{2}$

$E\left(\bar{x}_{s y}\right)=\frac{3}{6}\left(\frac{16}{3}\right)+\frac{3}{8}\left(\frac{12}{3}\right)+\frac{2}{8}\left(\frac{9}{2}\right)$

$=2+\frac{3}{2}+\frac{9}{8}=4,625$

$\bar{x}=\frac{1}{8}(6+3+4+9+2+5+1+7)=\frac{37}{8}=4,625$

Jadi $E\left(\bar{x}_{s y}\right)=\bar{X}$ (unbiased)

\section{Varians}

$$
\begin{aligned}
& V\left(X_{s y}\right)=\frac{1}{k} \sum_{i=1}^{k}(X i-\bar{X})^{2} \\
& V\left(\bar{X}_{s y}\right)=\frac{N-1}{N} S^{2}-\frac{1}{N} \sum_{i=1}^{k} \sum_{j=1}^{n}\left(X_{i j}-\bar{X}_{i}\right)^{2} \\
& S^{2}=\frac{1}{N} \sum_{i=1}^{k} \sum_{j=1}^{n}\left(X_{i j}-\bar{X}_{i}\right)^{2}
\end{aligned}
$$




$$
\begin{aligned}
& \frac{N-1}{N} S^{2} \text { tidak dipengaruhi susunan unit sample } \\
& \frac{1}{N} \sum_{i=1}^{k} \sum_{j=1}^{n}\left(X_{i j}-\bar{X}_{i}\right)^{2} \text { disebut pooled within varians dari k sampling systematik }
\end{aligned}
$$

Semakin besar nilai varians within, sampelnya semakin heterogen dan $\mathrm{V}\left(\mathrm{x}_{\mathrm{sys}}\right)$ makin kecil sehingga presisinya akan bertambah.

$\begin{array}{rlllllllll}\text { Misal (1) } & \# 1 & 2 & 2 & 2 & (2) & \# 1 & 2 & 3 & 4 \\ \# 2 & 3 & 3 & 3 & & \# 2 & 2 & 3 & 4 & \\ \# 3 & 4 & 4 & 4 & & \# 3 & 2 & 3 & 4 & \end{array}$

Catt \# : Kemungkinan sampel terpilih

- Introdass correlatif coefficient $(\rho)$

$\rho$ menunjukkan derajat homogenitas dari sampling sistematik.

$$
\begin{aligned}
& \rho=\frac{E\left(X_{i j}-\bar{X}\right)\left(X_{i j}{ }^{\prime}-\bar{X}\right)}{E\left(X_{i j}-\bar{X}\right)^{2}}=\frac{2}{n-1} \sum_{i=1}^{k} \sum_{j<j^{\prime}}^{n}\left(X_{i j}-\bar{X}\right)\left(X_{i j}{ }^{\prime}-\bar{X}\right)=\frac{1}{N-1} \frac{1}{S^{2}} \\
& V\left(X_{s y}\right)=S^{2} \frac{N-1}{N}[1+(n-1) \rho]
\end{aligned}
$$

- Jika $\rho$ makin besar dan positif (semakin keterogen unit dalam gugus sampel) maka $v\left(\bar{x}_{s y}\right)$ makin besar.

- Jika $\rho$ makin kecil dan positif atau negatif maka $v\left(\bar{x}_{s y}\right)$ makin kecil.

- Jika $\rho=0$ maka $V\left(\bar{x}_{s y}\right)=V\left(\bar{x}_{s r s}\right)$

\section{Contoh :}

Diketahui data populasi 1, 2, 3, 4, 5, 6, 7, 8, 9 kemudian diambil 3 sampel secara linier sistematik. Hitunglah V (Xsy) dengan 3 metode !

Jawab :

$1,2,3,4,5,6,7,8,9 . \quad \mathrm{N}=9, \quad \mathrm{k}=3, \quad \mathrm{n}=3$

\begin{tabular}{|l|l|l|l|l|l|}
\hline \multicolumn{2}{|l|}{ Sampel \#1 } & \multicolumn{2}{l|}{ Sampel \#2 } & \multicolumn{2}{l|}{ Sampel \#3 } \\
\hline $\mathrm{x}_{\mathrm{ij}}$ & $\mathrm{x}_{\mathrm{ij}}{ }^{2}$ & $\mathrm{X}_{2 \mathrm{j}}$ & $\mathrm{x}_{2 \mathrm{j}^{2}}$ & $\mathrm{x}_{3 \mathrm{j}}$ & $\mathrm{x}_{3 \mathrm{j}^{2}}$ \\
1 & 1 & 2 & 4 & 3 & 9 \\
4 & 16 & 5 & 25 & 6 & 36 \\
7 & 49 & 8 & 64 & 9 & 81 \\
\hline 12 & 66 & 15 & 93 & 18 & 126 \\
\hline
\end{tabular}


(1) $V\left(\bar{X}_{s y}\right)=\frac{1}{k} \sum_{i=1}^{k}(X i-\bar{X})^{2}=\frac{1}{3}\left[(4-5)^{2}+(5-5)^{2}+(6-5)^{2}\right]=\frac{2}{3}$

(2) $S^{2}=\frac{1}{N-1} \sum_{i=1}^{k} \sum_{j=1}^{n}(X i j-\bar{X} i)^{2}$

$$
\begin{aligned}
& =\frac{1}{9-1}\left[\sum_{j=1}^{3}\left(X_{1 j}-\bar{X}\right)^{2}+\sum_{j=1}^{3}\left(X_{2 j}-\bar{X}\right)^{2}+\sum_{j=1}^{3}\left(X_{3 j}-\bar{X}\right)^{2}\right] \\
& =\frac{1}{8}(21+18+21)=\frac{60}{8} \\
& V\left(\bar{X}_{s y}\right)=\frac{N-1}{N} S^{2}-\frac{1}{n} \sum_{i}^{k} \sum_{j}^{n}\left(X_{i j}-\bar{X}_{i}\right)^{2}=\frac{9-1}{9} \frac{60}{8}-\frac{1}{9}(18+18+18) \\
& =6 \frac{2}{3}-\frac{1}{6}=\frac{2}{3} \\
& \text { (3) } \sum_{j<j^{\prime}}^{3}\left(X_{i j}-\bar{X}\right)\left(X_{i j}^{\prime}-\bar{X}\right)=\left(X_{11}-\bar{X}\right)\left(X_{12}-\bar{X}\right)+\left(X_{11}-\bar{X}\right)\left(X_{13}-\bar{X}\right)\left(X_{12}-\bar{X}\right)\left(X_{13}-\bar{X}\right) \\
& =(1-5)(4-5)+(1-5)(7-5)+(5-5)(7-5)=-6
\end{aligned}
$$

Dengan cara yang sama untuk $\mathrm{i}=2$ kita dapatkan $-9, \mathrm{i}=3$ kita dapatkan $\mathrm{t}$

$$
\begin{aligned}
& \rho=\frac{2}{n-1} \sum_{i}^{k} \sum_{j<j^{\prime}}^{n}\left(X_{i j}-\bar{X}\right)\left(X_{i j}{ }^{\prime}-\bar{X}\right) \frac{1}{N-1} S^{2} \\
& =\frac{2}{3-1}(-6-9-6) \frac{1}{9-1} \frac{1}{60 / 8}=-\frac{21}{60} \\
& V\left(\bar{X}_{s y}\right)=\frac{S^{2}}{n} \frac{N-1}{N}[1+(n-1) \rho]=\frac{60 / 8}{3} \frac{9-1}{9}\left[1+(3-1)\left(-\frac{21}{60}\right)\right]=\frac{2}{3}
\end{aligned}
$$

\section{Estimasi Varians}

1) Metode acak (simple random sampling)

$$
\begin{aligned}
& V\left(\bar{X}_{s y}\right)=\frac{N-n}{N} \frac{S^{2}}{n} \\
& V(\hat{X})=N^{2} V\left(\bar{X}_{s y}\right)
\end{aligned}
$$

2) Paired selection model (Kish, 1965)

$$
V\left(\bar{X}_{s y}\right)=\frac{1-f}{n^{2}} \sum_{h=1}^{n / 2}\left(X_{h a}-X_{h b}\right)^{2}
$$

Jika n ganjil maka ambil satu sampel secara acak sehingga ada sampel yang 2 kali diperhitungkan. 
3) Successive difference model (Kish, 1965)

$$
V\left(\bar{X}_{s y}\right)=\frac{1-f}{2 n(n-1)} \sum_{g=1}^{n-1}\left(X_{g}-X_{g+1}\right)^{2}
$$

\section{Contoh:}

Berikut data hasil sensus RT. Dari 12 populasi RT, akan diambil 6 sampel dengan angka random pertama (R1) $=1$

$\mathrm{X}(\mathrm{RT})=\begin{array}{lllllllllllll}1 & 2 & 3 & 4 & 5 & 6 & 7 & 8 & 9 & 10 & 11 & 12\end{array}$

Hitung $v\left(\bar{x}_{s y}\right)$ dengan metode SRS, paired selection dan sucessive difference mode! Jawab :

$$
\text { Diket : } \mathrm{N}=12 ; \quad \mathrm{n}=6 ; \quad k=\frac{N}{n}=\frac{12}{6}=2
$$

maka $\quad \mathrm{R}_{\mathrm{n}}=\mathrm{R}_{1}+(\mathrm{n}-1) \mathrm{k}$

$$
\begin{aligned}
& \mathrm{R}_{2}=\mathrm{R}_{1}+\mathrm{k}=1+2=3 \\
& \mathrm{R}_{3}=\mathrm{R}_{1}+2 \mathrm{k}=1+4=5 \\
& \mathrm{R}_{4}=\mathrm{R}_{1}+3 \mathrm{k}=1+6=7 \\
& R_{5}=R_{1}+4 k=1+8=9 \\
& \mathrm{R}_{6}=\mathrm{R}_{1}+5 \mathrm{k}=1+10=11
\end{aligned}
$$

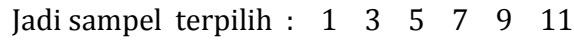

1. Metode SRS ;

$$
V\left(\bar{X}_{s y}\right)=\frac{N-n}{N} \frac{S^{2}}{n}=\frac{12-6}{12} \frac{14}{6}=\frac{1}{2} \frac{14}{6}=\frac{14}{12}=1,1667
$$

2. Paired selection model (Kish, 1965)

$$
\begin{array}{|l|l|l|}
\hline \mathbf{H} & \mathbf{X}_{\mathbf{h a}} & \mathbf{X}_{\mathbf{h b}} \\
\hline 1 & 1 & 3 \\
2 & 5 & 7 \\
3 & 9 & 11 \\
& V\left(\bar{X}_{s y}\right) & =\frac{1-f}{n^{2}} \sum_{h=1}^{n / 2}\left(X_{h a}-X_{h b}\right)^{2} \\
& =\frac{1-6 / 12}{6^{2}}\left[(1-3)^{2}+(5-7)^{2}+(9-11)^{2}\right]=\frac{1}{6}
\end{array}
$$

3. Successive difference model (Kish, 1965)

\begin{tabular}{|l|l|}
\hline $\mathbf{X}_{\mathbf{q}}$ & $\mathbf{X}_{\mathbf{q}+\mathbf{1}}$ \\
\hline 1 & 3 \\
3 & 5 \\
5 & 7 \\
7 & 9 \\
9 & 11 \\
\hline
\end{tabular}




$$
\begin{aligned}
V\left(\bar{X}_{s y}\right)= & \frac{1-f}{2 n(n-1)} \sum_{g=1}^{n-1}\left(X_{g}-X_{g+1}\right)^{2} \\
& =\frac{1-6 / 12}{2.6(6-1)}\left[(1-3)^{2}+(3-5)^{2}+(5-7)^{2}+(7-9)^{2}+(9-11)^{2}\right] \\
& =\frac{10}{60}=\frac{1}{6}
\end{aligned}
$$

\section{Efisiensi sistematik jika dibandingkan SRS}

$$
\text { Deff } \begin{aligned}
: \frac{V\left(\bar{X}_{s y}\right)}{V\left(\bar{X}_{s r s}\right)} & =\frac{\frac{N-1}{N} \frac{S^{2}}{n}[1+(n-1) \rho]}{\frac{N-n}{N} \frac{S^{2}}{n}} \\
& =\frac{(N-1)[1+(n-1) \rho]}{N-n}=\frac{(N-1)[1+(n-1) \rho]}{n(k-1)}
\end{aligned}
$$

Jika $:<1=>\quad$ sistematik lebih efesien

$=1 \Rightarrow$ sama efesien

$>1 \quad \Rightarrow \quad$ SRS lebih efesien

Jika : $\frac{V\left(\bar{X}_{s y}\right)}{V\left(\bar{X}_{s r s}\right)}=1$ maka $\rho=-\frac{1}{n k-1}=-\frac{1}{N-1}$

\section{STRATIFIED RANDOM SAMPLING}

Penarikan sampel berstrata adalah suatu metode dimana populasi yang berukuran $\mathrm{N}$, dibagi menjadi sub populasi - sub populasi yang masing -masing terdiri atas $N_{1}, N_{2}, N_{3}, N_{4}$, ..., $\mathrm{N}_{\mathrm{L}}$ elemen. Diantara dua sub populasi tidak boleh ada yang saling tumpang tindih. Sehingga $N_{1}+N_{2}+N_{3}+N_{4}+\ldots .+N_{L}=N$. Selanjutnya setiap anak populasi disebut sebagai Strata (stratum).

Dalam pembentukan strata terdapat persyaratan yakni :

1. Unit di dalam strata homogen

2. Variasi ysng terdapat antar strata besar ( heterogen)

3. Rata-rata setiap strata beda nyata (perbedaannya signifikan)

Adapun di dalam penerapannya penarikan sampel berstrata, kita dapat memperoleh keuntungan sebagai berikut :

1. Dengan sampel berstrata dapat diperoleh nilai estimasi dengan presisi lebih tinggi untuk setiap strata maupun untuk populasi secara keseluruhan.

2. Pada setiap strata yang dipergunakan rancangan penarikan sampel yang tergantung keadaan setiap strata dan kebutuhannya.

3. Setiap strata dapat dianggap sebagai populasi tersendiri, sehingga bisa saja menentukan presisi yang dikehendaki pada setiap strata dan disajikan tersendiri. 


\section{Rumus-rumus yang digunakan dalam Stratified Random Sampling}

Estimasi rata-rata populasi $\bar{Y}$

$$
\begin{aligned}
& \bar{Y}=\frac{1}{N} \sum_{h=1}^{L} \sum_{i=1}^{N h} Y h i=\frac{1}{N} \sum_{h=1}^{L} \mathrm{Nh} \bar{Y} h=\sum_{h=1}^{L} W h \bar{Y} h \\
& \text { dan : } \\
& \hat{Y}=\sum_{h=1}^{L} W h \bar{Y} h
\end{aligned}
$$

Yaitu bila pada setiap strata ditarik sampel secara bebas antar strata yang masingmasing berukuran nh, maka rata-rata sampel pada strata ke-h adalah $\bar{Y} h$ merupakan penjumlahan berbobot dari rata-rata sampel masing-masing strata.

Varians Populasi

$$
\sigma^{2}=\frac{1}{N} \sum_{h=1}^{L} \mathrm{Nh} \sigma \mathrm{h}^{2}+\frac{1}{N} \sum_{h=1}^{L} \mathrm{Nh}(\bar{Y} h-\bar{Y})
$$

Dimana varian populasi merupakan penjumlahaan dari variance di dalam strata dan variance antar strata

$$
\begin{array}{ll}
\sigma^{2} w=\frac{1}{N} \sum_{h=1}^{L} \operatorname{Nh} \sigma^{2} h & \text { (variance di dalam strata) } \\
\sigma^{2} b=\frac{1}{N} \sum_{h=1}^{L} \operatorname{Nh}(\bar{Y} h-\bar{Y}) & \text { (variance antar strata) }
\end{array}
$$

Varians Sampel

$$
V(\hat{Y} s t)=\sum_{h=1}^{L} W h^{2} \frac{(N h-n h)}{N h} \frac{S^{2} h}{n h}=\sum_{h=1}^{L} W h^{2}(1-f h) \frac{S^{2} h}{n h}
$$

Karena $\mathrm{sh}^{2}$ merupakan estimator tak bias bagi $\mathrm{Sh}^{2}$ maka estimasi bagi varians $\hat{Y}$ st : yang dihitung berdasarkan data sampel adalah :

$$
\begin{aligned}
\hat{V}(\hat{Y} s t) & =\sum_{h=1}^{L} W h^{2} \frac{(N h-n h)}{N h} \frac{s h^{2}}{n h} \\
& =\sum_{h=1}^{L} W h^{2}(1-f h) \frac{s h^{2}}{n h}
\end{aligned}
$$

\section{Pemilihan Sampel}

Ada beberapa metode mengalokasikan sampel ke dalam setiap strata, yaitu alokasi sembarang , alokasi sama (equal allocation), alokasi sebanding (proportional allocation), dan alokasi optimum(optimum allocation). Penerapan dari masing-masing metode tergantung pada ketersediaan informasi awal mengenai strata yang telah terbentuk.

a. Alokasi sembarang 
Misalkan suatu populasi berukuran $\mathrm{N}$ dibagi-bagi ke dalam L strata, sedemikian rupa sehingga $\mathrm{N}_{1}+\mathrm{N}_{2}+\mathrm{N}_{3}+\ldots .+\mathrm{N}_{\mathrm{L}}$ dan total ukuran $\mathrm{n}$ dialokasikan kesetiap strata secara sembarang ( berdasarkan pertimbangan subyektif peneliti) sedemikian rupa sehingga $\mathrm{n}_{1}+$ $\mathrm{n}_{2}+\mathrm{n}_{3}+\ldots .+\mathrm{n}_{1}=\mathrm{N}$

b. Alokasi sama (equal allocation)

Misalkan suatu populasi yang berukuran $\mathrm{N}$ dibagi-bagi ke dalam $\mathrm{L}$ strata sedemikian sehingga $\mathrm{N}_{1}+\mathrm{N}_{2}+\mathrm{N}_{3}+\ldots .+\mathrm{N}_{\mathrm{L}}=\mathrm{N}$ dan total ukuran $\mathrm{n}$ dialokasikan kesetiap strata secara sama, maka ukuran sampel pada setiap strata adalah :

$$
\mathrm{nh}=\frac{n}{L}=\bar{n}
$$

c. Alokasi sebanding (proportional allocation)

Alokasi sebanding dapat dipergunakan apabila rata-rata antara strata yang satu dengan yang lainnya berbeda sekali dan varians strata tidak tersedia. Keuntungan dari alokasi sebanding adalah kepraktisan pengolahan(tabulasi) hasil survey. Hal ini disebabkan karena dengan mengalokasikan sampel ke setiap strata sebanding dengan ukuran strata akan dihasilkan estimator-estimator yang tertimbang secara otomatis(self weighting).

d. Alokasi Optimum

Pada alokasi optimum kita mengalokasikan sampel yang berukuran $\mathrm{n}$ ke dalam setiap strata sedemikian rupa sehingga diperoleh varians sekecil mungkin dengan biaya yang tersedia atau meminimumkan biaya dengan varians tertentu.

Dengan melihat rumus-rumus yang digunakan untuk penentuan ukuran sampel, maka dapat disimpulkan, bahwa suatu strata tertentu , ukuran sampel lebih besar bila :

a. Ukuran strata lebih besar

b. Strata lebih bervariasi karakteristiknya (heterogen)

c. Strata yang biaya per unit sampelnya lebih murah.

Contoh :

1) Diketahui data populasi terbagi dalam strata berikut :

\begin{tabular}{|l|l|l|}
\hline Strata & Yhi & nh \\
\hline 1 & $2,3,5$ & 2 \\
\hline 2 & $6,4,7,8$ & 3 \\
\hline
\end{tabular}

a. Tentukan $\bar{Y} h, \bar{y} h, \bar{Y} s t, \bar{y} s t, \hat{Y} s t, \sigma^{2} b$ dan $\sigma^{2} w$

b. Tentukan $v(\bar{y} s t)$

Jawab :

Diketahui : $\mathrm{N}=7$,

$$
\mathrm{n}=5 \text { maka }
$$




$$
\mathrm{M}=\left(\begin{array}{c}
N 1 \\
n 1
\end{array}\right)\left(\begin{array}{l}
N 2 \\
n 2
\end{array}\right)=\left(\begin{array}{l}
3 \\
2
\end{array}\right)\left(\begin{array}{l}
4 \\
3
\end{array}\right)=4 \times 4=12
$$

\begin{tabular}{|l|l|l|l|l|l|l|l|l|}
\hline Strata & $N h$ & $n h$ & $\bar{Y} h$ & $\bar{Y} s t$ & $\sigma^{2} h$ & $\sigma^{2} b$ & $\sigma^{2} w$ & $S^{2} h$ \\
\hline 1 & 3 & 2 & $10 / 3$ & 5 & 1,6 & 2 & 0,7 & 2,335 \\
\hline 2 & 4 & 3 & 6,25 & & 2,2 & 5 & 1,3 & 2,9 \\
\hline
\end{tabular}

Aps
\begin{tabular}{|l|l|l|l|l|l|l|}
\hline Strata 1 & Strata 2 & $\bar{y} 1$ & $\bar{y} 2$ & $\bar{y} s t$ & $s^{2} 1$ & $s^{2} 2$ \\
\hline 23 & 647 & 2,5 & 5,7 & 4,3 & 0,5 & 2,335 \\
\hline 23 & 648 & 2,5 & 6 & 4,5 & 0,5 & 4 \\
\hline 23 & 678 & 2,5 & 7 & 5,1 & 0,5 & 1 \\
\hline 23 & 478 & 2,5 & 6,3 & 4,7 & 0,5 & 4,335 \\
\hline 25 & 647 & 3,5 & 5,7 & 4,8 & 4,5 & 2,335 \\
\hline 25 & 648 & 3,5 & 6 & 4,9 & 4,5 & 4 \\
\hline 25 & 678 & 3,5 & 7 & 5,5 & 4,5 & 1 \\
\hline 25 & 478 & 3,5 & 6,3 & 5,1 & 4,5 & 4,335 \\
\hline 35 & 647 & 4 & 5,7 & 4,97 & 2 & 2,335 \\
\hline 35 & 648 & 4 & 6 & 5,1 & 2 & 4 \\
\hline 35 & 678 & 4 & 7 & 5,7 & 2 & 1 \\
\hline 35 & 478 & 4 & 6,3 & 5,3 & 2 & 4,335 \\
\hline
\end{tabular}

$$
\text { b. } \begin{aligned}
v(\bar{y} s t) & =\frac{1}{N^{2}} \sum N h(N h-n h) \frac{S^{2} h}{n h} \\
& =\frac{1}{49}\left[\frac{3(3-2)(2,335)}{2}+\frac{4(4-3)(2,9)}{3}\right]=0,15
\end{aligned}
$$

2) Bagian promosi kesehatan ingin memperkirakan rata-rata waktu selama seminggu yang dipergunakan penduduk (anggota rumah tangga) untuk melihat siaran televisi yang menyiarkan iklan kampanye kesehatan. Penduduk sebagai populasi dibagi menjadi 3 stratum. Stratum I yang tinggal dekat pabrik ( sebagian besar karyawan pabrik), stratum II penduduk yang tinggal dekat pertokoan ( sebagian karyawan toko) dan Stratum III mereka yang tinggal di pinggiran kota sebagai petani. Biaya sama untuk setiap stratum yaitu 
$\sigma i=10$, untuk semua i. Tujuan penelitian yaitu ingin memperkirakan rata-rata waktu melihat siaran televisi per minggu bagi seluruh rumah tangga dengan kesalahan sampling 2 jam.

Diketahui data :

$\begin{array}{ccc}\text { Stratum I } & \text { Stratum II } & \text { Stratum III } \\ \text { N1 }=155 & \text { N2 }=62 & \text { N3 }=93\end{array}$

Gunakan proportional sampling! Jawab :

Oleh karena $\mathrm{Ci}=1, \quad \sigma \mathrm{i}=10$ untuk semua I, maka :

$$
\begin{aligned}
& n i=\left[\frac{N i}{n}\right] n \\
& n_{1}=\left[\frac{N_{1}}{N}\right] n=\left[\frac{155}{310}\right] n=0,5 n \\
& n_{2}=\left[\frac{N_{2}}{N}\right] n=\left[\frac{62}{310}\right] n=0,2 n \\
& n_{3}=\left[\frac{N_{3}}{N}\right] n=\left[\frac{93}{310}\right] n=0,3 n \\
& w i=\frac{N h}{N} \\
& w_{1}=0,5 \\
& B=2 \sigma \bar{x} s t=2 \rightarrow \sigma \bar{x} s t=1 \\
& \mathrm{D}=\frac{B^{2}}{4}=\frac{4}{4}=1 \text { dan } N^{2} D=(310)^{2}(1)=96100 \\
& \sigma i=10 \text { untuk semua i } \\
& \sum_{i=1}^{3} \frac{N i^{2} \dot{\sigma}^{2}}{W i}=\frac{N_{1} \sigma_{1}}{W_{1}}+\frac{N_{2} \sigma_{2}}{W_{2}}+\frac{N_{3} \sigma_{3}}{W_{3}} \\
& \text { ni }=\mathrm{nWi}=(155)(100)+(62)(100)+(93)(100) \\
& \mathrm{n}_{1}=(76)(0,5)=38 ; \mathrm{n}_{2}=(76)(0,2)=15 ; \mathrm{n}_{3}=(76)(0,3)=23
\end{aligned}
$$

\section{Stratified Random Sampling Untuk Proporsi}

Misalkan suatu populasi dengan $\mathrm{N}$ elemen dibagi menjadi $\mathrm{L}$ strata sedemikian rupa sehingga $\mathrm{N}_{1}+\mathrm{N}_{2}+\mathrm{N}_{3}+\ldots .+\mathrm{N}_{\mathrm{L}}=\mathrm{N}$, dan Yhi adalah nilai variable kualitatif Y dalam strata ke-h pada unit ke-i. Elemen-elemen dengan ciri termasuk dalam kategori R masing-masing diberi nilai 1, sedangkan untuk kategori lainnya diberi nilai 0. Populasi elemen-elemen dalam strata ke-h yang termasuk kategori R adalah

$$
P h=\frac{1}{N h} \sum_{i=1}^{N h} Y h i
$$


dan variansnya adalah

$$
S^{2} h=\frac{N h}{N h-1} P h(1-P h)=\frac{N h}{N h-1} P h Q h
$$

Proporsi elemen-elemen dalam populasi yang termasuk R kategori dapat dinyatakan sebagai

$$
P=\sum_{h=1}^{L} \frac{N h}{N} P h
$$

Bila pada masing-masing strata ditarik sampel berukuran nh, maka estimator tak bias bagi P adalah

$$
p s t=\sum_{h=1}^{L} \frac{N h}{N} p h \quad \text { dimana } p h=\frac{1}{n h} \sum_{i=1}^{n h} Y h i
$$

dan estimator variansnya

$$
V(p s t)=\frac{1}{N^{2}} \sum_{h=1}^{L} N^{2} h \frac{N h-n h}{N h} \frac{N h}{N h-1} \frac{P h Q h}{n h}
$$

dugaan tak bias bagi varians proporsi yang didasarkan pada data sampel adalah

$$
v(p s t)=\frac{1}{N^{2}} \sum_{h=1}^{L} N^{2} h \frac{N h-n h}{N h} \frac{N h}{N h-1} \frac{p h q h}{n h}
$$

Misalkan $\mathrm{V}$ merupakan varians yang diinginkan dalam memperkirakan proporsi $\mathrm{P}$ untuk seluruh populasi. Rumus untuk dua jenis alokasi yang utama adalah sebagai berikut :

Proporsional :

$$
n_{0}=\frac{\sum W_{h} p_{h} q_{h}}{V} ; n=\frac{n_{0}}{1+\frac{n_{0}}{N}}
$$

Optimum yang diperkirakan :

$$
n_{0}=\frac{\left(\sum W h \sqrt{p h q h}\right)^{2}}{V} ; n=\frac{n_{0}}{1+\frac{1}{N V} \sum W h p h q h}
$$

dimana $\mathrm{n}_{0}$ adalah pendekatan pertama yang mengabaikan $\mathrm{kpt}$, dan $\mathrm{n}$ adalah nilai terkoreksi yang diperoleh dengan menghitung kpt dalam pengembangan rumus ini, factor $N h(N h-1)$ telah diambil sebagai kesatuan.

\section{Contoh :}

Seorang mahasiswa semester akhir akan mengadakan penelitian mengenai rumah tangga kurang mampu di suatu desa. Rumah tangga dibagi menjadi strata, dan pengambilan sampel dilakukan setiap strata, dan diperoleh informasi rata-rata pengeluar per rumah tangga untuk setiap sampel desa. Yang termasuk dalam kategori rumah tangga kurang mampu apabila berpenghasilan $<$ Rp 500.000,- / tahun. 
Datanya sebagai berikut :

\begin{tabular}{|l|l|l|lll|}
\hline Strata & $\begin{array}{l}\text { Rumah Tangga } \\
(\mathrm{Nh})\end{array}$ & $\begin{array}{l}\text { Rumah Tangga terpilih } \\
(\mathrm{nh})\end{array}$ & Penghasilan (000) \\
\hline 1 & 12 & 6 & 500300150550175450 \\
\hline 2 & 10 & 5 & 675550500220350 \\
\hline 3 & 8 & 4 & 175250225575 & \\
\hline 4 & 10 & 5 & 800725150250150 \\
\hline
\end{tabular}

Hitunglah $\hat{p}$ estimasi proporsi rumah tangga kurang mampu di desa tersebut, beserta senya!

Jawab :

$$
\begin{array}{rlrl}
p h & =\frac{1}{n h} \sum_{i=1}^{n h} X h i & & \\
p_{1}=4 / 6 \quad \mathrm{p}_{3}=3 / 4 & q_{1}=2 / 6 & q_{3}=1 / 4 \\
p_{2}=2 / 5 \quad \mathrm{p}_{4}=3 / 5 & q_{2}=3 / 5 & \\
\hat{p} s t r & =\frac{\sum_{i=1}^{N} N h P h}{N} & & \\
& =\frac{1}{40}[12.4 / 6+10.2 / 5+8.3 / 4+10.3 / 5]=24 / 40 &
\end{array}
$$

Jadi dari 40 rumah tangga yang ada, ada 24 rumah tangga yang kurang mampu di desa tersebut

$$
\begin{aligned}
& v(p) \text { str }=\frac{1}{N^{2}} \sum_{h=1}^{L} N^{2} h \frac{N h-n h}{N h} \frac{1}{n h} \frac{N h}{N h-1} p h q h \\
& =\frac{1}{40^{2}}\left[\left(12^{2} \frac{12-6}{12} \frac{1}{6} \frac{12}{11} \frac{4}{6} \frac{2}{6}\right)+\left(10^{2} \frac{10-5}{10} \frac{1}{5} \frac{10}{9} \frac{1}{5} \frac{1}{5} \frac{3}{5} \frac{3}{5}\right)+\left(8^{2} \frac{8-4}{5} \frac{1}{4} \frac{8}{7} \frac{3}{4} \frac{1}{4}\right)+\right] \\
& =\frac{1}{1600}[9,95671]=0,006223 \\
& S e=\sqrt{v(p) s t r}=\sqrt{0,006223}=0,0789
\end{aligned}
$$




\section{CLUSTER RANDOM SAMPLING}

1. Hambatan utama yang dihadapi dalam simple random sampling (SAS), sistematik sampling, dan stratified random sampling adalah harus tersedianya kerangka sampling yang lengkap sejak awal pemilihan.

2. Menyusun kerangka sampling bukan pekerjaan mudah, memerlukan biaya yang besar dan waktu yang relatif lama, terutama apabila populasi sasaran yang akan diteliti ruang lingkupnya besar.

3. Untuk menghindari kesukaran dalam menyusun kerangka sampling, peneliti biasanya menggunakan rencana sampling lain sebagai alternatif, yaitu cluster sampling. Dalam cluster ini mengusahakan agar karakteristik dalam cluster heterogen sedangkan antar cluster homogen.

4. Dengan demikian yang dimaksud dengan cluster adalah sebuah unit sampling yang didalamnya masih berisi unit-unit analisis yang lebih kecil.

5. Membentuk sampling frame yang unit-unitnya terdiri dari cluster lebih mudah ketimbang membentuk sampling frame yang terdiri dari unit yang lebih kecil. Pada stratifikasi, pembentuk stratifikasi dasarnya adalah membentuk subpopulasi yang keadaan variabelnya relatif homogen.

6. Apabila dipandang dari tingkat sekolahnya maka SD < SMP dan SMU dapat dikatakan homogen. Pada masalah membentuk cluster, dasarnya adalah membentuk kesatuan yang keadaan variabelnya heterogen.

7. Dalam prakteknya membentuk cluster yang artifical yang betul-betul memenuhi sifat heterogen sangat sukar dilakukan.

\section{E. PROBABILITY PROPORTIONAL TO SIZE (PPS)}

Dalam penarikan sampel acak sederhana peluang setiap unit untuk terpilih menjadi sampel adalah sama untuk setiap unit dalam populasi. Pada umumnya setiap unit sampling dalam populasi ukurannya bervariasi, maka penerapan penarikan sampel acak sederhana bukan merupakan prosedur yang tepat.

Bila setiap unit sampling dalam populasi dilengkapi dengan informasi tambahan (auxiliary information) yang sering disebut sebagai size, maka informasi tersebut dapat digunakan sebagai dasar pertimbangan dalam penarikan sampel sehingga dapat diperoleh estimator dari parameter yang lebih efisien. Informasi tambahan yang digunakan sebagai dasar penarikan sampel haruslah informasi yang memiliki korelasi yang erat dengan variabel-variabel yang akan diteliti. Prosedur penarikan sampel dimana terpilihnya suatu unit sampling adalah sebanding dengan ukuran (size) disebut probability proportional to size sampling atau PPS sampling. 


\section{A. Prosedur Penarikan Sampel}

a. Metode Kumulatif

Apabila sampel berukuran $\mathrm{n}$ dipilih dari suatu populasi berukuran N secara PPS-WR dengan $\mathrm{X}_{\mathrm{i}}$ sebagai ukuran dari unit ke-i, tahapan penarikan sampelnya adalah sebagai berikut;

1. Buat kumulatif dari size yang digunakan sebagai dasar penarikan sampel untuk seluruh unit dalam populasi yaitu: $\mathrm{X}_{1},\left(\mathrm{X}_{1}+\mathrm{X}_{2}\right),\left(\mathrm{X}_{1}+\mathrm{X}_{2}+\mathrm{X}_{3}\right), \ldots$;

$\sum x_{i}=X$

2. Pilih angka random (Rk) yang besarnya antara 1 sampai dengan $X\left(1 \leq R_{k} \leq X\right)$

3. Unit ke-k terpilih sebagai sampel bila kondisi $\sum_{i=1}^{k-1} x_{i}+1 \leq \mathrm{R}_{\mathrm{k}} \leq \sum_{i=1}^{k} x_{i}$ terpenuhi. Bila kondisi tersebut tidak terpenuhi, ulangi langkah ke-2.

Ulangi langkah ke-2 sampai mendapat $\mathrm{n}$ sampel yang dibutuhkan.

\section{Example :}

1) Berikut ini adalah daftar 10 pemilik pabrik tahu beserta jumlah pekerja yang ada pada suatu kota. Untuk mengetahui rata-rata limbah industri yang dihasilkan tiap harinya, dipilih sampel sebanyak 4 pabrik secara PPS-WR dengan ukuran jumlah pekerja yang dimiliki oleh pabrik.

Tabel 1: Daftar kerangka Pemilihan pemilik pabrik

\begin{tabular}{|l|l|l|l|l|}
\hline No & $\begin{array}{l}\text { Nama Pemilik } \\
\text { Pabrik }\end{array}$ & $\begin{array}{l}\text { Jumlah Pekerja } \\
\text { (Xi) }\end{array}$ & $\begin{array}{l}\text { Kumulatif Jlh } \\
\text { Pekerja }\end{array}$ & Range \\
\hline 1. & Bibbie & 25 & 25 & $1-25$ \\
2. & Fahrie & 14 & 39 & $26-39$ \\
3. & Ribut & 40 & 79 & $40-79$ \\
4. & Muchlis & 9 & 88 & $80-88$ \\
5. & Nova & 31 & 119 & $89-119$ \\
6. & Kiki & 18 & 137 & $120-137$ \\
7. & Rini & 12 & 149 & $138-149$ \\
8. & Dayni & 7 & 156 & $150-156$ \\
9. & Juwita & 41 & 197 & $157-197$ \\
10. & Bundo & 27 & 224 & $198-224$ \\
\hline
\end{tabular}

a. Misalnya angka random yang terpilih adalah sebagai berikut: 003, 218, 179, 067.

b. Rumah tangga yang terpilih adalah: 
Tabel 2: Lembar kerja Pemilihan Sampel pemilik Pabrik

\begin{tabular}{|l|l|l|l|}
\hline $\begin{array}{l}\text { Angka } \\
\text { Random }\end{array}$ & $\begin{array}{l}\text { No. urut yg berpadanan } \\
\text { Dgn range }\end{array}$ & $\begin{array}{l}\text { Nama Pemilik } \\
\text { Pabrik }\end{array}$ & $\begin{array}{l}\text { Jumlah } \\
\text { Pekerja }\end{array}$ \\
\hline 003 & 1 & Bibbie & 25 \\
218 & 10 & Bundo & 27 \\
179 & 9 & Juwita & 41 \\
067 & 3 & Ribut & 40 \\
\hline
\end{tabular}

\section{b. Metode Lahiri}

Metode lahiri tidak membutuhkan kerangka sampel yang memuat jumlah kumulatif dari size unit sampling dalam populasi. Apabila sampel berukuran $\mathrm{n}$ dipilih dari populasi yang berukuran $\mathrm{N}$ secara PPS-WR dengan $\mathrm{X}_{\mathrm{i}}$ sebagai size unit ke-i. Tahapan penarikan sampelnya sebagai berikut;

1. Pilih dua angka random secara serentak, yaitu:

- $\quad R_{i}^{(1)}$ yang besarnya antara 1 sampai dengan $\mathrm{N}\left(1 \leq R_{i}^{(1)} \leq \mathrm{N}\right)$, angka random ini berkenaan dengan nomor urut sampling dalam populasi.

- $R_{i}^{(2)}$ yang besarnya antara 1 sampai dengan $X_{\max }\left(1 \leq R_{i}^{(2)} \leq X_{\max }\right)$ angka random ini berkenaan dengan size yang digunakan sebagai dasar penarikan sample.

2. Bila angka random kedua $\left(R_{i}^{(2)}\right) \leq x_{i}$, maka unit ke-i terpilih sebagai sampel. Sebaliknya bila kondisi ini terpenuhi, maka bangkitkan 2 angka random lagi secara serentak.

3. Ulangi langkah ke-2 sampai mendapat $\mathrm{n}$ sampel yang dibutuhkan.

2) Berikut ini adalah daftar 10 pemilik pabrik tahu beserta jumlah pekerja yang dimiliki. Untuk mengetahui rata-rata limbah yang dihassilkan, dipilih sampel sebanyak 4 pabrik secara PPS-WR dengan ukuran jumlah pekerja yang dimiliki oleh pabrik.

Tabel 3: Daftar Kerangka Pemilihan Pabrik

\begin{tabular}{|l|l|l|}
\hline No & $\begin{array}{l}\text { Nama pemilik } \\
\text { pabrik }\end{array}$ & Jumlah Kader yang Dimiliki $\left(\mathbf{X}_{\mathbf{i}}\right)$ \\
\hline 1. & Bibbie & 25 \\
2. & Fahrie & 14 \\
3. & Ribut & 40 \\
\hline
\end{tabular}




\begin{tabular}{|l|l|l|}
\hline 4. & Muchlis & 9 \\
5. & Nova & 31 \\
6. & Kiki & 18 \\
7. & Rini & 12 \\
8. & Dayni & 7 \\
9. & Juwita & 41 \\
10. & Bundo & 27 \\
\hline
\end{tabular}

a. $1 \leq R_{i}^{(1)} \leq 10$ dan $1 \leq R_{i}^{(2)} \leq 41$

b. Berikut angka random dan nama pemilik yang terpilih:

Tabel 4: Lembar Kerja Pemilihan pabrik

\begin{tabular}{|l|l|l|l|l|l|}
\hline \multicolumn{2}{|l|}{ Angka Random } & \multirow{2}{*}{ Xi } & \multirow{2}{*}{ Keputusan } & \multicolumn{2}{l|}{ pabrik Terpilih } \\
\cline { 1 - 3 } Ri(1) & Ri(2) & & & No. urut & Nama pemilik \\
\hline 02 & 13 & 14 & Terima & 2 & Fahrie \\
09 & 96 & 41 & Tolak & - & - \\
04 & 01 & 9 & Terima & 4 & Muchlis \\
07 & 12 & 12 & Terima & 7 & Rini \\
09 & 31 & 41 & Terima & 9 & Juwita \\
\hline
\end{tabular}

Catatan: Tidak semua angka random yang dipilih dan ditolak ditampilkan dalam tabel di atas.

Metode Lahiri digunakan sebenarnya hanya untuk menghindari perhitungan kumulatif karena size unit yang cukup besar.

a. Metode PPS Sistematik

Apabila sampel berukuran $\mathrm{n}$ dipilih dari suatu populasi berukuran $\mathrm{N}$ dan $\mathrm{X}$ adalah total size maka interval ( I) penarikan sampelnya adalah:

$$
I=\frac{X}{n}=\frac{1}{n} \sum_{i=1}^{N} X_{i}
$$

1. Apabila I adalah Integer (bilangan bulat) maka digunakan Sistematik Linear. Misalkan Ri adalah angka random pertama (Random Start) yang lebih kecil atau sama dengan I, maka unit-unit yang berpadanan dengan 
$R_{i}=R_{1}+(i-1) ~ I ; i=1,2, \ldots, N$ akan terpilih sebagai sampel secara umum unit ke- $\mathrm{i}$ terpilih sebagai sampel apabila dipenuhi kondisi:

$$
\sum^{i-1} X_{i}<R_{i}<\sum^{i} X_{i} \text { atau } \sum^{i-1} X_{i}<\left(R_{i}+(i-1) I\right)<\sum^{i} X_{i}
$$

2. Apabila I bukan Integer (bilangan bulat) maka gunakan Sistematik Sirkuler. Dalam Sistematik Sirkuler angka random pertama (Random Start) besarnya antara 1 sampai dengan $\mathrm{X}$, tidak harus lebih kecil dari interval.

\section{Example :}

3) Berikut ini adalah daftar 10 pemilik pabrik tahu beserta jumlah pekerja yang dimiliki. Untuk mengetahui rata-rata limbah yang dihassilkan, dipilih sampel sebanyak 4 pabrik secara PPS-WR dengan ukuran jumlah pekerja yang dimiliki oleh pabrik.

Tabel 1: Daftar kerangka Pemilihan Pabrik

\begin{tabular}{|l|l|l|l|l|}
\hline No & $\begin{array}{l}\text { Nama Pemilik } \\
\text { Pabrik }\end{array}$ & $\begin{array}{l}\text { Jumlah pekerja } \\
\text { (Xi) }\end{array}$ & $\begin{array}{l}\text { Kumulatif Jml } \\
\text { Pekerja }\end{array}$ & Range \\
\hline 1. & Bibbie & 25 & 25 & $1-25$ \\
2. & Fahrie & 14 & 39 & $26-39$ \\
4. & Ribut & 40 & 79 & $40-79$ \\
5. & Muchlis & 9 & 88 & $80-88$ \\
6. & Kiki & 31 & 119 & $89-119$ \\
7. & Rini & 18 & 137 & $120-137$ \\
8. & Dayni & 12 & 149 & $138-149$ \\
9. & Juwita & 71 & 156 & $150-156$ \\
10. & Bundo & 27 & 197 & $157-197$ \\
\hline
\end{tabular}

Jawab :
a. $I=\frac{224}{4}=56 \quad$ Angka random terpilih pertama adalah 03. 


$$
\begin{aligned}
& \mathrm{R}_{1}=03 \\
& \mathrm{R}_{2}=\mathrm{R}_{1}+(2-1) 56=3+56=59 \\
& \mathrm{R}_{3}=\mathrm{R}_{1}+(3-1) 56=3+112=115 \\
& \mathrm{R}_{4}=\mathrm{R}_{1}+(4-1) 56=3+168=171
\end{aligned}
$$

b. Maka pemilik yang terpilih adalah:

\begin{tabular}{|l|l|l|l|}
\hline \multirow{2}{*}{ Ri } & No. urut yang berpadanan & Pemilik Terpilih \\
\cline { 3 - 4 } & dengan Range & Nama pemilik & $\begin{array}{l}\text { Jumlah } \\
\text { Pekerja }\end{array}$ \\
\hline 3 & 1 & Bibbie & 25 \\
59 & 3 & Ribut & 40 \\
115 & 5 & Nova & 31 \\
171 & 9 & Juwita & 41 \\
\hline
\end{tabular}

\section{B. Prosedur Estimasi}

a. PPS - WR ( Hunsen - Hurwitz estimator )

Pada suatu penarikan sampel sebanyak $\mathrm{n}$ unit yang diambil dari sebuah populasi dengan ukuran $\mathrm{N}$ unit secara PPS-WR dengan size $\mathrm{X}_{\mathrm{i}}$, maka besarnya peluang terpilihnya unit ke-i sebagai sampel adalah:

$$
P_{i}=\frac{x_{i}}{\sum_{i=1}^{N} x_{i}}=\frac{x_{i}}{X}
$$

Misalnya $Y_{i}$ adalah nilai variabel yang berpadanan dengan terpilihnya unit ke-i maka estimator yang unbiased bagi total adalah:

$$
\hat{Y}_{i}=\frac{y_{i}}{p_{i}}=X \frac{y_{i}}{x_{i}}
$$

$\hat{Y}_{i}(\mathrm{i}=1,2, \ldots, \mathrm{n})$ merupakan estimator-estimator yang unbiased bagi total Y dan saling independent. Maka kombinasi dari estimator-estimator tersebut merupakan estimator yang unbiased bagi total $Y$, yaitu:

$$
\hat{Y}_{P P S}=\frac{1}{n} \sum_{i=1}^{n} \hat{Y}_{i}=\frac{X}{n} \sum_{i=1}^{n} \frac{y_{i}}{x_{i}}
$$


dan estimasi rata-ratanya sebesar:

$$
\hat{\bar{Y}}_{P P S}=\frac{\hat{Y}}{N}
$$

varians total populasinya sebesar :

$$
V\left(\hat{Y}_{P P S}\right)=\frac{1}{n} \sum_{i=1}^{N} p_{i}\left(\hat{Y}_{i}-Y_{P P S}\right)^{2}=\frac{1}{n} \sum_{i=1}^{N} p_{i}\left(\frac{y_{i}}{p_{i}}-Y_{P P S}\right)^{2}
$$

dan estimatornya:

$$
v\left(\hat{Y}_{P P S}\right)=\frac{1}{n(n-1)} \sum_{i=1}^{n}\left(\frac{y_{i}}{p_{i}}-\hat{Y}_{P P S}\right)^{2}=\frac{1}{n(n-1)}\left(\sum_{i=1}^{n} \frac{y_{i}{ }^{2}}{p_{i}{ }^{2}}-n \hat{Y}_{P P S}{ }^{2}\right)
$$

varians rata-rata populasi:

$$
V\left(\hat{\bar{Y}}_{P P S}\right)=\frac{V\left(\hat{Y}_{P P S}\right)}{N^{2}}
$$

dan estimatornya:

$$
v\left(\hat{\bar{Y}}_{P P S}\right)=\frac{v\left(\hat{Y}_{P P S}\right)}{N^{2}}
$$

b. PPS Random / WOR ( tanpa pemulihan )

PPS WOR dapat memberikan efisiensi yang lebih baik dibanding WR. Banyak sampel dalam praktek yang telah dilakukan dengan pengembalian WOR tetapi prosedur

\begin{tabular}{|c|c|c|}
\hline Strata & Size Unit Dalam Populasi ( $\left.x_{h i}\right)$ & Sampel $x_{h i}$ \\
\hline 1 & $\mathrm{X}_{11}, \mathrm{X}_{12, \ldots \ldots \ldots \ldots \ldots \ldots \ldots \ldots}$ & $\mathrm{X}_{11}, \mathrm{X}_{12}, \ldots \ldots \ldots \ldots \ldots . . . . . . . . \mathrm{X}_{1 \mathrm{~N} 1}$ \\
\hline 2 & 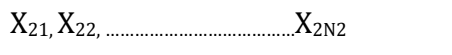 & $\mathrm{X}_{21}, \mathrm{X}_{22}, \ldots \ldots \ldots \ldots \ldots, \mathrm{X}_{2 \mathrm{~N} 2}$ \\
\hline - & $\cdot \quad \cdot$ & $\cdot$. \\
\hline$\cdot$ & $\cdot \quad \cdot$ & $\cdot \cdot$ \\
\hline . &.$\quad$. & . . \\
\hline $\mathrm{h}$ & $\mathrm{X}_{\mathrm{h} 1}, \mathrm{X}_{\mathrm{h} 2, \ldots \ldots \ldots \ldots \ldots \ldots \ldots \ldots \ldots \ldots \ldots \ldots \ldots \ldots \ldots \ldots \ldots \ldots \ldots \ldots}$ & $\mathrm{X}_{\mathrm{h} 1}, \mathrm{X}_{\mathrm{h} 2, \ldots \ldots \ldots \ldots \ldots . . . . . . . .} \mathrm{X}_{\mathrm{hNh}}$ \\
\hline
\end{tabular}
perhitungan lebih kompleks dan tidak mudah diaplikasikan. Jika fraksi sampling kecil, dalam survey skala besar, efisiensi WR atau WOR akan berbeda tidak nyata (hampir sama). Meskipun begitu, jika fraksi besar efisiensi WOR akan lebih substansial.

C. PPS Stratified Sampling 
Besarnya peluang terpilihnya unit ke-I sebagai sampel :

$$
\begin{aligned}
P_{h i} & =\frac{X_{h i}}{\sum X_{h i}} & p_{h i}=\frac{x_{h i}}{\sum X_{h i}} \\
\hat{Y}_{P P S} & =\sum \hat{Y}_{h}^{L} & \hat{\bar{Y}}_{P P S}=\frac{\hat{Y}_{P P S}}{\sum N_{h}} \\
& =\sum \frac{1}{n_{h}} \sum^{n_{h}} \frac{y_{h i}}{P_{h i}} & \hat{\bar{Y}}_{h}=\frac{\hat{Y}_{h}}{N_{h}} \\
& =\sum \frac{X}{X_{h}} \sum_{h}^{n_{h}} \frac{y_{h i}}{x_{h i}} &
\end{aligned}
$$

varians

$$
\begin{aligned}
V\left(\hat{Y}_{P P S}\right) & =V\left(\sum \hat{Y}_{h}^{L}\right) \\
& =\sum^{L}\left(V\left(\hat{Y}_{h}\right)\right) \\
& =\sum \frac{1}{n_{h}} \sum^{N_{h}}\left(\frac{Y_{h i}}{P_{h i}}-Y_{h}\right)^{2} P_{h i} \\
\hat{V}\left(\hat{Y}_{P P S}\right) & =\sum^{L} \frac{1}{n_{h}\left(n_{h}-1\right)} \sum^{n_{h}}\left(\frac{y_{h i}}{p_{h i}}-\hat{Y}_{h}\right)^{2}
\end{aligned}
$$

Proportional:

$$
n_{h}=\frac{X_{h}}{X} n
$$

Optimum:

$$
\text { - Fixed } \mathrm{n} \sim n_{h}=n \sqrt{V_{h}}
$$




$$
\begin{gathered}
=\sum \sqrt{V_{h}} \\
V_{h}=\sum^{N_{h}}\left(\frac{Y_{h i}}{P_{h i}}-Y_{h}\right)^{2} P_{h i} \\
\text { - Fixed cost } \sim n_{h}=\frac{\left(c-c_{0}\right) \sqrt{\frac{V_{h}}{c_{h}}} n}{\sum \sqrt{\frac{V_{h}}{c_{h}}}} \\
c-c_{0}=\sum C_{h} N_{h}
\end{gathered}
$$

\section{F. MULTISTAGE RANDOM SAMPLING}

\section{DEFINISI}

Prosedur pengambilan sample dimana Dari N first sampling unit (fsu) dipilih $\mathrm{n}$ unit, dan dari $\mathrm{M}_{i}$ unit second sampling unit (ssu) dipilih $\mathrm{m}_{i}$ unit.

Biasanya Penarikan sample dua tahap ini dilakukan dengan cara

\section{$\hookrightarrow$ Tahap I}

mengambil sebanyak $\mathrm{n}$ cluster dari $\mathrm{N}$ cluster dari populasi..

\section{Tahap II}

Dari n cluster yang terpilih masing-masing memiliki cluster-cluster lagi dengan unit yang berbeda dari unit pada tahap pertama dengan ukuran $M_{i}$ dari unit sebanyak $M_{i}$ tersebut kita lakukan pengambilan sample lagi sebanyak $m_{i}$ untuk masing-masing cluster

\begin{tabular}{|c|c|c|c|c|c|}
\hline \multirow{2}{*}{ Tahap } & \multicolumn{2}{|c|}{ Banyaknya unit di dalam } & \multirow{2}{*}{$\begin{array}{l}\text { Metode } \\
\text { Penarikan } \\
\text { sampel }\end{array}$} & \multirow{2}{*}{$\begin{array}{l}\text { Peluang } \\
\text { pemilihan } \\
\text { sampel }\end{array}$} & \multirow{2}{*}{$\begin{array}{l}\text { Fraksi } \\
\text { sampling }\end{array}$} \\
\hline & Populasi & Sampel & & & \\
\hline $\begin{array}{l}\text { Pertam } \\
\text { a }\end{array}$ & $\mathbf{N}$ & $n$ & SRS-WOR & $\frac{1}{N}$ & $\frac{n}{N}$ \\
\hline Kedua & $M_{i}$ & $m_{i}$ & SRS-WOR & $\frac{1}{M_{i}}$ & $\frac{m_{i}}{M_{i}}$ \\
\hline
\end{tabular}
yang terpilih pada pengambilan sample tahap pertama.

\section{KEDUA TAHAP SRS WOR}

Tabel 1. Penarikan sampel dua tahap dengan metode SRS-WOR pada kedua tahap 

a. Faktor pengali penarikan sampel tahap pertama, $\mathrm{F} 1=\frac{1}{f_{1}}=\frac{N}{n}$
b. Faktor pengali penarikan sampel tahap kedua, $\mathrm{F}_{2 \mathrm{i}}=\frac{1}{f_{21}}=\frac{M_{i}}{m_{i}}$
c. Faktor pengali keseluruhan, $\mathrm{F}=\mathrm{F}_{1} \mathrm{~F}_{2 \mathrm{i}}$ yang berbeda antar pstp, kecuali bila $\mathrm{F}_{2 \mathrm{i}}$ $\mathrm{F}_{2}$ konstan, maka $\mathrm{F}=\mathrm{F}_{1} \mathrm{~F}_{2}$ merupakan desain tertimbang sendiri (self- weighting design).

\section{TAHAP PERTAMA PPS-WR DAN TAHAP KEDUA SRS-WOR}

Tabel 1.3. Penarikan sampel dua tahap dengan metode PPS-WR tahap pertama dan SRS-WOR tahap kedua

\begin{tabular}{|c|c|c|c|c|c|}
\hline \multirow{2}{*}{ Tahap } & \multicolumn{2}{|c|}{ Banyaknya unit di dalam } & \multirow{2}{*}{$\begin{array}{l}\text { Metode } \\
\text { Penarikan } \\
\text { sampel }\end{array}$} & \multirow{2}{*}{$\begin{array}{l}\text { Peluang } \\
\text { pemilihan } \\
\text { sampel }\end{array}$} & \multirow{2}{*}{$\begin{array}{l}\text { Fraksi } \\
\text { sampling }\end{array}$} \\
\hline & Populasi & Sampel & & & \\
\hline $\begin{array}{l}\text { Pertam } \\
\text { a }\end{array}$ & $N$ & $n$ & PPS-WR & $\frac{x_{I}}{X}$ & $n \frac{x_{i}}{X}$ \\
\hline Kedua & $M_{i}$ & $m_{i}$ & SRS-WOR & $\frac{1}{M_{i}}$ & $\frac{m_{i}}{M_{i}}$ \\
\hline
\end{tabular}

$$
\begin{aligned}
& \hat{Y}_{i}=\frac{1}{p_{i}} \frac{M_{i}}{m_{i}} \sum_{j=1}^{m_{i}} y_{i j}=\frac{X M_{i}}{x_{i} m_{i}} \sum_{j=1}^{m_{i}} y_{i j} \text { bila } \mathrm{X}_{\mathrm{i}}=\mathrm{M}_{\mathrm{i}} \text { maka } \hat{Y}_{i}=\frac{M_{o}}{M_{i}} \frac{M_{i}}{m_{i}} \sum_{j=1}^{m_{i}} y_{i j} \\
& \hat{Y}=\frac{1}{n} \sum_{i=1}^{n} \hat{Y}_{i}
\end{aligned}
$$$$
V(\hat{Y})=\frac{1}{n} \sum_{i=1}^{N}\left(\frac{Y_{i}}{P_{i}}-Y\right)^{2} P_{i}+\frac{1}{n} \sum_{i=1}^{N} \frac{M_{i}^{2}}{P_{i}}\left(1-f_{i}\right) \frac{S_{i}^{2}}{m_{i}}
$$$$
v(\hat{Y})=\frac{1}{n(n-1)} \sum_{i=1}^{n}\left(\hat{Y}_{i}-\hat{Y}\right)^{2}
$$ 


\section{G. MULTIPHASE RANDOM SAMPLING}

\section{Konsep Dasar}

- Multiphase sampling adalah pengambilan sampel berdasarkan informasi yang diperoleh pada fase pertama yang digunakan sebagai informasi tambahan untuk memperoleh estimasi yang akurat pada fase berikutnya

- Multiphase sampling yang biasa digunakan adalah double sampling (two phase sampling)

Double sampling mencakup pemilihan sampel sebesar $\mathrm{n}$ tidak secara langsung dari populasi berukuran N, tetapi melalui pemilihan sampel sebelumnya sebesar n'.
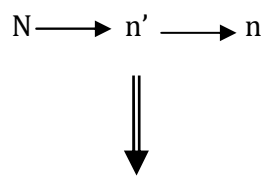

Informasi yang diperoleh dari n'

digunakan untuk meningkatkan

keakuratan estimasi sampel akhir.

- Perbedaan multiphase dan multistage

$\checkmark$ Pada multiphase, tiap unit sampel yang diambil pada fase yang berbeda adalah sama, hanya karakteristik yang diukur berbeda

$\checkmark$ Pada multistage, tiap unit sampel yang diambil pada tiap stage berbeda.

- Double sampling biasanya digunakan bersama-sama dengan stratified sampling dan ratio estimate.

\section{Rumus Estimasi}

- $\quad$ Stratified double sampling

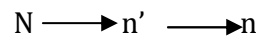

Fase I :Dari populasi sebesar $\mathrm{N}$ diambil sampel sebesar n'. berdasarkan informasi yang diperoleh dari pengambilan sampel ini, dibuat stratifikasi untuk n' dimana $\sum_{\mathrm{h}=1}^{\mathrm{H}} \mathrm{n}_{\mathrm{h}}{ }^{\prime}=\mathrm{n}^{\prime}$ 
Fase II : Dari setiap $\mathrm{n}_{\mathrm{h}}$ 'diambil sampel masing-masing sebesaar $\mathrm{n}_{\mathrm{h}}$ dimana $\sum_{\mathrm{h}=1}^{\mathrm{H}} \mathrm{n}_{\mathrm{h}}=\mathrm{n}$

- Estimasi rata-rata dari total populasi

$$
\overline{\mathrm{y}}_{\mathrm{sdb}}=\sum_{\mathrm{h}=1}^{\mathrm{H}} \mathrm{w}_{\mathrm{h}} \overline{\mathrm{y}}_{\mathrm{h}},
$$

dimana

$$
\begin{aligned}
& \mathrm{w}_{\mathrm{h}}=\frac{\mathrm{n}_{\mathrm{h}}{ }^{\prime}}{\mathrm{n}^{\prime}} \\
& \bar{y}_{\mathrm{h}}=\frac{1}{\mathrm{n}_{\mathrm{h}}{ }^{\prime}} \sum_{\mathrm{i}=1}^{\mathrm{n}_{\mathrm{h}}} \mathrm{y}_{\mathrm{i}}
\end{aligned}
$$

- Estimasi total populasi

$$
\hat{\mathrm{Y}}_{\mathrm{sdb}}=\hat{\mathrm{N}} \overline{\mathrm{y}}_{\mathrm{sdb}}
$$

dimana

$$
\hat{\mathrm{N}}=\frac{\mathrm{B}}{\mathrm{b}} \mathrm{n}
$$

- Estimasi varians estimasi rata-rata total

$$
\mathrm{v}\left(\overline{\mathrm{y}}_{\mathrm{sdb}}\right)=\frac{\mathrm{n}^{\prime}}{\left(\mathrm{n}^{\prime}-1\right)} \sum_{\mathrm{h}=1}^{\mathrm{H}}\left[\left\{\mathrm{w}^{2}{ }_{\mathrm{h}}-\mathrm{g} \frac{\mathrm{w}_{\mathrm{h}}}{\mathrm{n}^{\prime}}\right\} \frac{\mathrm{s}^{2}{ }_{\mathrm{h}}}{\mathrm{n}_{\mathrm{h}}}+\mathrm{gw}_{\mathrm{h}}\left\{\frac{\overline{\mathrm{y}}_{\mathrm{h}}-\overline{\mathrm{y}}_{\mathrm{sfb}}}{\mathrm{n}^{\prime}}\right\}^{2}\right]
$$

dimana

$$
\mathrm{g}=\frac{\mathrm{N}-\mathrm{n}^{\prime}}{\mathrm{N}-1}, \text { bila sampel }<5 \% \text { maka } \mathrm{g} \sim 1
$$

- Estimasi Varian total:

$$
\mathrm{v}\left(\hat{\mathrm{Y}}_{\mathrm{sdb}}\right)=\hat{\mathrm{N}}^{2} \mathrm{v}\left(\overline{\mathrm{y}}_{\mathrm{sdb}}\right)
$$

- standar error:

$$
\begin{aligned}
& \operatorname{se}\left(\overline{\mathrm{y}}_{\mathrm{sdb}}\right)=\sqrt{\mathrm{v}\left(\overline{\mathrm{y}}_{\mathrm{sdb}}\right)} \\
& \operatorname{se}\left(\hat{\mathrm{Y}}_{\mathrm{sdb}}\right)=\sqrt{\mathrm{v}\left(\hat{\mathrm{Y}}_{\mathrm{sdb}}\right)}
\end{aligned}
$$

keterangan

B : total blok sensus

$\mathrm{b}$ : blok sensus terpilih

- Double sampling dalam ratio estimate 
Fase I : Dari populasi sebesar $\mathrm{N}$ diambil sampel sebesar n'. Dari n' dikumpulkan informasi mengenai variabel tambahan untuk memperbaiki estimasi, misal $\mathrm{x}$.

Fase II : Dari n' diambil sampel sebesar $n$. dari $\mathrm{n}$ juga dikumpulkan informasi mengenai $\mathrm{x}$.

- Estimasi rata-rata populasi

$$
\begin{aligned}
& \overline{\mathrm{y}}_{\mathrm{rd}}=\frac{\overline{\mathrm{y}}}{\overline{\mathrm{x}}^{\prime}} \cdot \overline{\mathrm{x}}^{\prime}, \text { dimana } \overline{\mathrm{x}}=\frac{1}{\mathrm{n}} \sum_{\mathrm{i}=1}^{\mathrm{n}} \mathrm{x}_{\mathrm{i}} \rightarrow \text { diperoleh dari fase II } \\
& \overline{\mathrm{x}}^{\prime}=\frac{1}{\mathrm{n}^{\prime}} \sum_{\mathrm{i}=1}^{\mathrm{n}^{\prime}} \mathrm{x}_{\mathrm{i}} \rightarrow \text { diperoleh dari fase I }
\end{aligned}
$$

- Estimasi total populasi

$$
\hat{\mathrm{Y}}_{\mathrm{rd}}=\mathrm{N} \overline{\mathrm{y}}_{\mathrm{rd}}
$$

- Estimasi varians estimasi rata-rata

$$
\mathrm{v}\left(\overline{\mathrm{y}}_{\mathrm{rd}}\right)=\left(\frac{1}{\mathrm{n}}-\frac{1}{\mathrm{n}^{\prime}}\right)\left(\mathrm{s}_{\mathrm{y}}{ }^{2}+\hat{\mathrm{R}} \mathrm{s}_{\mathrm{x}}{ }^{2}-2 \hat{\mathrm{R}} \mathrm{s}_{\mathrm{xy}}{ }^{2}\right)+\left(\frac{1}{\mathrm{n}^{\prime}}-\frac{1}{\mathrm{~N}}\right) \mathrm{s}_{\mathrm{y}}{ }^{2}
$$

- Estimasi varians total

$$
\mathrm{v}\left(\hat{\mathrm{Y}}_{\mathrm{rd}}\right)=\hat{\mathrm{N}}^{2} \mathrm{v}\left(\overline{\mathrm{y}}_{\mathrm{rd}}\right)
$$

- Standar error

$$
\begin{aligned}
& \operatorname{se}\left(\overline{\mathrm{y}}_{\mathrm{rd}}\right)=\sqrt{\mathrm{v}\left(\overline{\mathrm{y}}_{\mathrm{rd}}\right)} \\
& \operatorname{se}\left(\hat{\mathrm{Y}}_{\mathrm{rd}}\right)=\sqrt{\mathrm{v}\left(\hat{\mathrm{Y}}_{\mathrm{rd}}\right)} \\
& \operatorname{dimana} \mathrm{s}_{\mathrm{y}}{ }^{2}=\frac{\sum_{\mathrm{i}=1}^{\mathrm{n}}\left(\mathrm{y}_{\mathrm{i}}-\overline{\mathrm{y}}\right)^{2}}{\mathrm{n}-1} \\
& \mathrm{~s}_{\mathrm{x}}{ }^{2}=\frac{\sum_{\mathrm{i}=1}^{\mathrm{n}}\left(\mathrm{x}_{\mathrm{i}}-\overline{\mathrm{x}}\right)^{2}}{\mathrm{n}-1} \\
& \mathrm{~s}_{\mathrm{xy}}=\frac{\sum_{\mathrm{i}=1}^{\mathrm{n}}\left(\mathrm{x}_{\mathrm{i}}-\mathrm{x}\right)\left(\mathrm{y}_{\mathrm{i}}-\mathrm{y}\right)}{\mathrm{n}-1}
\end{aligned}
$$




\section{BAB IV \\ METODE NON PROBABILITA SAMPLING}

A. CONVINIENCE SAMPLING

\section{Konsep Dasar}

- Sampel diambil berdasarkan pada ketersediaan elemen dan kemudahan untuk mendapatkannya

- Sampel terpilih karena berada pada waktu dan tempat yang tepat

- Cara ini biasanya dipakai pada tahap awal penelitian

- Kelebihan :

- Murah dan cepat (hemat biaya dan waktu)

- Cocok untuk pilot study

- Kekurangan :

- Hasilnya tidak dapat diandalkan

- Tidak dapat digiunakan bila populasi tidak dapat didefinisikan

\section{Contoh Aplikasi}

Penelitian tentang persepsi konsumen terhadap pelayanan. Penelitian dilaksanakan selama satu minggu. Sampel yang diambil adalah sebesar 100 orang. Konsumen yang akan terpilih sebagai sampel adalah 100 orang pertama yang ditemui di toko tersebut selama kurun waktu penelitian.

\section{B. JUDGEMENT SAMPLING}

\section{Konsep Dasar}

- Judgment sampling merupakan pengambilan sampel berdasarkan kriteria yang telah ditentukan

- Kriteria pengambilan sampel ada dua yaitu,

\section{A. Expert sampling}

Pemilihan sampel yang representatif didasarkan atas pendapat ahli sehingga siapa dan jumlah sampel yang diambil tergantung pada pendapat ahli yang bersangkutan.

B. Purposive sampling

Pemilihan sampel berdasarkan pada penelitian pribadi peneliti yang menyatakan bahwa sampel yang dipilih benar-benar representaif. Peneliti harus memiliki pengetahuan yang memadai.

- Kelebihan :

- Bila probability sampling tidak dapat digunakan sama sekali 
- Bila sampel sangat kecil $(<20)$

- Bila pengetahuan peneliti tentang topik yang dihadapi sangat memadai

- Kekurangan :

- Perlu kejelian peneliti dalam mendefinisikan populasi dan membuat pertimbangannya.

\section{Contah Aplikasi}

Penelitian tentang 'sikap dan perilaku konsumen terhadap rokok Djarum' Judgment yang diambil adalah sebagai berikut:

a. Para perokok di Jakarta Utara yang pernah mencoba rokok Djarum. Batasan ini diambil karena

pertama dipilih Jakarta Utara karena mungkin dari letak geografisnyanya para responden mudah diakses,

Kedua dipilih para perokok untuk menghindari adanya bias dari hasil penelitian karena adanya sikap yang bertolak belakang antara perokok dan bukan perokok.

Ketiga dipilih yang pernah mencoba rokok Djarum.

b. Pria/wanita yang berusia 15 tahun ke atas dan perokok. Hal ini didasarkan pada faktor kejiwaan yang menyatakan bahwa orang-orang pada usia 15 diharapkan sudah dapat memutuskan dan menjawab/mengisi angket dengan benar. Tidak adanya pembedaan antara pria dan wanita disebabkan kenyataan pada dewasa ini bahwa rokok bukan sepenuhnya dikonsumsi oleh para pria saja.

c. Periode penyebaran dan pengumpulan angket dibatasi selama 2 minggu. Judgment ini biasanya dipilih dalam kaitannya dengan efisiensi waktu dan biaya yang tersedia.

\section{QUOTA SAMPLING}

\section{Konsep Dasar}

- Quota sampling dapat juga disebut sebagai judgment sampling dua tahap dimana :

Tahap I $\longrightarrow$ Peneliti merumuskan kategori kontrol atau quota dari populasi yang akan diteliti

Tahap II $\longrightarrow \quad$ Penentuan bagaimana sampel akan diambil, dapat secara convinience atau judgment, tergantung situasi dan kondisi penelitian serta kemampuan peneliti

- Perbedaan antara judgment dengan quota terletak pada adanya suatu batasan pada quota sampling. Dalam quota sampling, sampling yang diambil telah dijatah (quotum) dari setiap sub kelompoknya.

- Kelebihan :

- biaya penelitian rendah

- keleluasaan peneliti untuk menentukan elemen-elemen untuk setiap quotanya

- Kekurangan : 
- tingginya tingkat kesulitan dalam merumuskan hasil penelitian karena data yang diperoleh sangat beragam

- tidak ada prosedur baku bagi pewawancara dan teknik wawancara akan berpengaruh pada terjadinya bias.

- Quota sampling termasuk dalam nonprobability sampling sehingga tidak bisa untuk mengestimasi populasi.

\section{Contoh Aplikasi}

Penelitian mengenai kebiasaan membaca koran dari orang dewasa di Jakarta yang diperkirakan berjumlah 4 juta orang.

Kategori kontrol yang dipakai adalah :

a. jenis kelamin (laki-laki dan perempuan)

b. usia (18-31, 31- $\left.45,46-60,>60^{\text {th }}\right)$

Misal sampel yang akan diambil adalah 10.000 orang dan dari populasi diperoleh informasi bahwa

a. Jenis kelamin : Laki-laki : $60 \%$

$$
\text { Perempuan : } 40 \%
$$

b. Usia

$$
\begin{gathered}
: 18-30==>40 \% \\
31-45==>30 \% \\
46-60==>23 \% \\
>60==>7 \%
\end{gathered}
$$

Atas dasar informasi tersebut maka, komposisi dari 10.000 sampel harus mengandung:

- $60 \%$ laki-laki dan $40 \%$ perempuan

- $40 \%$ berusia $18-30$ tahun , $30 \%$ berusia $31-45$ tahun, $23 \%$ berusia $46-60$ tahun, dan $7 \%$ berusia $>60$ tahun.

$\square$

\section{SNOWBALL SAMPLING}

\section{Konsep Dasar}

- Snowball sampling tidak digunakan bila populasinya sangat spesifik, dan antara anggota populasi saling mengenal.

- Sampel diambil secara berantai, mulai dari ukuran sampel yang kecil, makin lama semakin menjadi besar.

- Kelebihan : bias relatif kecil karena populasinya spesifik dan sampelnya terfokus.

- Kekurangan: biaya dan waktu yang diperlukan untuk memperoleh informasi cukup besar.

\section{Contoh Aplikasi}

Penelitian mengenai pendapat ahli penyakit dalam senior Indonesia terhadap pengobatan penyakit dalam dengan menggunakan tenaga dalam. Dalam pelaksanaannya, pertama-tama dilakukan wawancara terhadap seoran gahli penyakit dalam. Selanjutnya dari yang bersangkutan diminta untuk menunjukan beberapa ahli lain untuk diwawancarai. Demikian seterusnya hingga diperoleh sejumlah responden yang diperlukan. 


\section{BAB V \\ BESAR SAMPEL}

\section{A. MENENTUKAN UKURAN SAMPEL}

Hal yang paling banyak dipersoalkan orang ketika melakukan penelitian adalah ukuran sampel. Ketepatan jenis dan ukuran sampel yang diambil akan sangat mempengaruhi keterwakilan populasi (representativeness) sampel terhadap populasi. Keterwakilan populasi akan sangat menentukan kebenaran kesimpulan dari hasil penelitian. Secara umum ada kecenderungan bahwa semakin besar ukuran sampel akan semakin mewakili populasi. Rata-rata dan simpangan baku sampel akan mewakili rata-rata dan simpangan baku dari populasi. Di lain pihak, para peneliti ingin bekerja dengan sampel sekecil mungkin, sebab makin besar ukuran sampel akan semakin besar biaya yang akan dikeluarkan, makin banyak tenaga yang digunakan dan makin lama waktu yang diperlukan.

Berdasarkan literatur yang penulis pelajari, terdapat tiga kelompok dari ahli dalam menentukan ukuran sampel:

1. Ukuran sampel yang didasarkan atas pertimbangan persentase dan kecenderungan umum, dengan memperhatikan ukuran populasi.

Winarno Surachmad (1990), Suharsimi Arikunto(1990), Kartini Kartono (1990), menyatakan bahwa ukuran sampel sangat ditentukan oleh besarnya ukuran populasi. Untuk populasi dengan ukuran kurang dari seratus, sampel dapat diambil seluruhnya (seluruh anggota populasi menjadi sampel atau disebut juga sebagai sampel total). Namun demikian, Burhan Bungin (2005), memiliki pendapat bahwa ukuran sampel dapat dihitung dengan menggunakan rumus:

$$
\mathrm{n}=\frac{\mathrm{N}}{\mathrm{N} \cdot \mathrm{d}^{2}+1}
$$

Keterangan:

$\mathrm{n}=$ Ukuran sampel

$\mathrm{N}=$ Ukuran Populasi

$\mathrm{d}=$ nilai presisi/ketepatan meramalkan .

Contoh:

Apabila ukuran sampel sebesar 4.540, dengan presisi sebesar $10 \%(0,1)$ maka ukuran sampel dapat diperoleh sebesar $97,84 \approx 98$ orang.

Adapula rumus sampling yang dikemukakan oleh Hadari Nawawi (1983) dengan rumus: 
$n \geq p q\left(\frac{Z_{1 / 2 \alpha}}{b}\right)^{2}$

Keterangan:

$\begin{array}{lll}\mathrm{n} & = & \text { ukuran sampel } \\ \mathrm{Z} & = & \text { sama dengan atau lebih dari } \\ \mathrm{p} & = & \text { proporsi populasi persentase kelompok pertama } \\ \mathrm{q} & = & \text { proporsi sisa di dalam populasi } \\ \mathrm{Z} 1 / 2 \alpha & = & \text { besarnya harga } \mathrm{Z} \text { untuk } \alpha \text { tertentu }(95 \% \text { atau } 99 \%) \\ \mathrm{b} & = & \text { persentase perkiraan kemungkinan membuat kekeliruan } \\ & & \text { dalam menentukan sampel }\end{array}$

Contoh:

Jika diketahui jumlah guru SMA di Jawa Barat 400.000 orang, di antara mereka yang tinggal di daerah perdesaan sebanyak 5.000 orang. Berapa ukuran sampel yang diperlukan untuk penelitian di atas.

Proporsi mereka yang tinggal di perdesaan adalah 5.000/400.000 $\times 100 \%=$ $12,5 \%$ atau $\mathrm{p}=0,125$.

$\mathrm{q}=1-0,125=0,875$.

$\mathrm{Z} 1 / 2 \alpha$ untuk $\alpha=0,05$ adalah 1,96 .

Kemungkinan membuat kekeliruan sebesar $5 \%$ atau 0,05.

Dimasukkan ke dalam rumus, sehingga diperoleh:

$n \geq 0,125 \times 0,875\left(\frac{1,96}{0,05}\right)^{2}=168,05=169$

2. Ukuran sampel yang didasarkan atas pertimbangan hasil ujicoba yang dilakukan, dengan memperhatikan skor rata-rata dan simpangan baku. Sutaryat Trisnamansyah (1984), mengemukakan bahwa ukuran sampel yang diperlukan dalam penelitian ditentukan oleh hasil ujicoba terhadap sebagian dari populasi yang dimaksud dalam penelitian. Hasil yang diperhitungkan untuk menghitung ukuran sampel digunakan rumus:

$$
n o=\frac{\mathrm{Z}_{1 / 2 \alpha}{ }^{2} \cdot \mathrm{s}^{2}}{\mathrm{~b}^{2}} \text { dan } n=\frac{\text { no }}{1+\frac{\mathrm{no}}{\mathrm{N}}}
$$

Keterangan:

no $=$ Ukuran sampel minimal menurut perkiraan pertama

$\mathrm{n} \quad=$ Ukuran sampel minimal

$\mathrm{N}=$ Ukuran populasi

$\mathrm{Z}$ = Harga yang diambil dari daftar distribusi normal baku menurut taraf signifikansi tertentu

$\mathrm{s}=$ Simpangan baku yang diperoleh secara empiris (dari hasil penelitian pendahuluan) 
$\mathrm{X}=$ Rata-rata yang diperoleh secara empiris (dari hasil penelitian pendahuluan)

$\mathrm{b}=$ Perbedaan antara rata-rata yang sebenarnya dengan rata-rata yang ditaksir yang dapat ditoleransikan. Untuk menentukan bias ini dipergunakan rumus:

$b^{2}=\frac{\mathrm{Z}_{1 / 2 \alpha}{ }^{2} \cdot \mathrm{s}^{2}}{\mathrm{X}}$

Contoh:

Diketahui:

$\mathrm{N}=2000$

$\mathrm{Z}_{1 / 2 \alpha}$ untuk $\alpha=0,05$ adalah 1,96 .

Rata-rata Skor Variabel X1 = 110,7736 dengan s = 20,8323

$$
\begin{aligned}
& b^{2}=\frac{(1,96)^{2} \cdot(20,8323)^{2}}{110,7736}=15.0504787511723 \mathrm{~b}=3.87949465152001 \\
& n o=\frac{(1,96)^{2} \cdot(20,8323)^{2}}{15,050479}=110.7736 \\
& n=\frac{110,7736}{1+\frac{110,7736}{2000}}=104.96019089873=105
\end{aligned}
$$

3. Ukuran sampel yang didasarkan atas pertimbangan teknik analisis yang dipergunakan dalam penelitian. Matchin \& Campbel (1989)

Salah satu teknik yang dipergunakan untuk menentukan ukuran sampel adalah dengan memoertimbangkan jenis teknik analisis dan jumlah variabel bebas yang akan diuji. Apabila pengujian menggunakan teknik analisis hubungan (baik korelasional maupun kausal) antara berbagai variabel yang diidentifikasi digunakan Freund's Iterative Method. Langkah-langkah yang digunakan untuk menentukan besarnya ukuran sampel dengan teknik ini adalah:

a. Tentukan berdasarkan perkiraan besarnya pengaruh yang ditimbulkan oleh variabel endogen terhadap variabel eksogen. Sebagai contoh bahwa variabel eksogen dipengaruhi oleh variabel endogen paling tidak sebesar $10 \%$ atau $\left(\rho^{2}=0,10\right.$, sehingga $\left.\rho=0,30\right)$.

b. Tentukan besarnya a (Kekeliruan tipe I) dan b (kekeliruan tipe II). Kekeliruan tipe I merupakan kekeliruan untuk menolak Ho yang seharusnya diterima dan kekeliruan tipe II adalah kekeliruan untuk menolah $\mathrm{H} 1$ yang seharusnya diterima. Besarnya peluang untuk menolak Ho dinyatakan oleh $\alpha$, sedangkan besarnya peluang untuk menolah $\mathrm{H} 1$ dinyatakan oleh $\beta$.

c. Lakukan Iterasi minimal 2 kali dengan ketentuan bahwa; jika besarnya nilai numerik satuan $\mathrm{n}_{1}$ dan $\mathrm{n}_{2}$ sudah sama, iterasi berhenti dan 
menentukan besarnya sampel dengan membulatkan angka ke atas. Sedangkan jika $\mathrm{n}_{1}$ dan $\mathrm{n}_{2}$ tidak sama, maka iterasi dilanjutkan.

d. Adapun rumus yang dipergunakan adalah:

$$
\begin{aligned}
U^{\prime} \rho & =1 / 2 \ln \left(\frac{1+\rho}{1-\rho}\right) \\
n & =\frac{\left(Z_{\alpha}+Z_{\beta}\right)^{2}}{U^{\prime} \rho^{2}}+3
\end{aligned}
$$

1) Iterasi pertama

kedua terlebih dahulu dihitung:

$$
\begin{aligned}
& \mathrm{U}^{2} \boldsymbol{\rho}=1 / 2 \ln \left(\frac{1+\rho}{1-\rho}\right)+\frac{\rho}{2(\mathrm{n}-1)} \\
& \mathrm{n}=\frac{\left(\mathrm{Z}_{\alpha}+\mathrm{Z}_{\beta}\right)^{2}}{\mathrm{U}^{2} \boldsymbol{\rho}^{2}}+3
\end{aligned}
$$

3) Iterasi kedua

\section{Contoh:}

Seorang peneliti bermaksud menguji pengaruh yang menyatakan bahwa Sikap Agresif Terhadap Kelompok Luar (SATKL) dipengaruhi oleh Autoritarianisme Struktur, Dogmatisme Ide, dan Sektarian Religious.

Dalam hal ini terdapat 3 variabel endogen dan 1 variabel eksogen. Untuk menentukan besarnya ukuran sampel, ditentukan berdasarkan menggunakan rumus yang dikemukakan di atas, dengan ketentuan:

a. Peneliti menduga bahwa variabel eksogen paling tidak sebesar $10 \%$ ditentukan oleh ketiga variabel endogen tersebut. Oleh karena itu diketahui besarnya $\rho^{2}=0,1$ atau $\rho=0,3$.

b. Besarnya tingkat kepercayaan adalah $95 \%$, sehingga $\alpha=0,05$ dan power sebesar 95\% ( $\beta=1-0,95=0,05$. Oleh karena itu, besarnya Z $\alpha$ (untuk $\alpha=$ 0,05 ) adalah 1,645 (hasil interpolasi linier), dan besarnya Z $\beta$ (untuk $\beta=$ 0,05 ) adalah 1,645 (hasil interpolasi linier).

c. Melakukan Iterasi:

1) Iterasi Pertama

$$
\begin{gathered}
\mathrm{U}^{\prime} \rho=1 / 2 \ln \left(\frac{1+0,3}{1-0,3}\right)=0,154759802 \\
\mathrm{n}=\frac{(1,645+1,645)^{2}}{(0,154759802)^{2}}+3=115,9836
\end{gathered}
$$

2) untuk menghitung Iterasi kedua, terlebih dahulu dicari:

$$
\mathrm{U}^{2} \rho=1 / 2 \ln \left(\frac{1+0,3}{1-0,3}\right)+\frac{0,3}{2(115-1)}=0,156076
$$


3) Iterasi kedua

$$
\mathrm{n}=\frac{(1,645+1,645)^{2}}{(0,156076)^{2}}+3=114,0866
$$

Oleh karena hasil iterasi pertama dan kedua belum menunjukkan satuan yang sama, maka iterasi dilanjutkan ke iterasi ketiga.

Sebelum menghitung iterasi ketiga, terlebih dahulu dicari:

$$
\mathrm{U}^{3} \rho=1 / 2 \ln \left(\frac{1+0,3}{1-0,3}\right)+\frac{0,3}{2(114-1)}=0,156087
$$

4) Iterasi ketiga

$$
\mathrm{n}=\frac{(1,645+1,645)^{2}}{(0,156087)^{2}}+3=114,0701
$$

Hasil iterasi kedua dan ketiga menunjukkan satuan angka yang sama yaitu 115 (hasil pembulatan ke atas), sehingga ditentukan batas minimal ukuran sampel yang diambil adalah 115 .

\section{PENGHITUNGAN VARIANS DAN ANALISIS VARIANS}

Dalam menentukan besar sampel, ada beberapa rumus yang menggunakan perhitungan varians dan standart deviasi. Berikut sedikit dijelaskan tentang varians dan standart deviasi.

\section{A. Varians}

Varians merupakan salah satu ukuran dispersi atau variasi. Ukuran ini mengisyaratkan keseragaman atau keberagaman suatu data. Berbeda dengan ukuran gejala pusat, ukuran variasi tidak pernah diperoleh harga negatif, meskipun data yang dimiliki semuanya negatif. Apabila diperoleh harga untuk ukuran variasi sama dengan nol, artinya data yang dimiliki tidak bervariasi, demikian pula sebaliknya, semakin harga variasi menjauhi harga nol, data yang dimiliki semakin bervariasi. Selain varians, ukuran variasi lainnya adalah rentang, simpangan baku, dan indeks dispersi.

Harga varians sebenarnya merupakan ukuran simpangan kuadrat, sehingga di dalam perhitungannya melibatkan angka kuadrat dari setiap data yang dimiliki. Untuk menghitung varians digunakan rumus:

$$
\begin{aligned}
& \sigma^{2}= \frac{\sum \mathrm{X}_{\mathrm{i}}^{2}-\frac{\left(\sum \mathrm{X}_{\mathrm{i}}\right)^{2}}{\mathrm{~N}}}{\mathrm{~N}} ; \text { apabila dihitung dari populasi (parameter) } \\
& \mathrm{s}^{2}=\frac{\sum \mathrm{X}_{\mathrm{i}}^{2}-\frac{\left(\sum \mathrm{X}_{\mathrm{i}}\right)^{2}}{\mathrm{n}}}{\mathrm{n}-1} ; \text { apabila dihitung dari sampel (statistik) }
\end{aligned}
$$


Kedua pendekatan rumus di atas menggunakan rumus kuadrat terkecil. Beberapa ahli memperkenalkan pula penghitungan varians dengan menggunakan skor-skor simpangan yang ditulis dengan rumus:

$\sigma^{2}=\frac{\sum \mathrm{x}^{2}}{\mathrm{~N}} ;$ apabila varians dihitung dari populasi

$s^{2}=\frac{\sum \mathrm{x}^{2}}{\mathrm{n}-1} ;$ apabila varians dihitung dari sampel

\section{Contoh:}

Untuk menghitung varians dengan pendekatan kuadrat terkecil dari suatu kumpulan data yang terdiri dari skor: 4,5,6,7,8 dapat dilakukan dengan cara di bawah ini

\begin{tabular}{|l|l|l|}
\hline No. & $\mathbf{X}$ & $\mathbf{X}^{2}$ \\
\hline 1 & 4 & 16 \\
\hline 2 & 5 & 25 \\
\hline 3 & 6 & 36 \\
\hline 4 & 7 & 49 \\
\hline 5 & 8 & 64 \\
\hline$\Sigma$ & 30 & 190 \\
\hline
\end{tabular}

Dari data di atas dapat dihitung variansnya adalah:

$$
\begin{gathered}
\sigma^{2}=\frac{190-\frac{(30)^{2}}{5}}{5}=2=\text { varians untuk poupulasi } \\
\mathrm{s}^{2}=\frac{190-\frac{(30)^{2}}{5}}{5-1}=2.5=\text { varians untuk sampel }
\end{gathered}
$$

sedangkan apabila rumus yang dipergunakan adalah skor-skor simpangan, maka data yang dibutuhkan adalah:

\begin{tabular}{|l|l|l|l|}
\hline No. & $\mathbf{X}$ & $\mathbf{X}$ & $\mathbf{X}^{\mathbf{2}}$ \\
\hline 1 & 4 & -2 & 4 \\
\hline 2 & 5 & -1 & 1 \\
\hline 3 & 6 & 0 & 0 \\
\hline 4 & 7 & 1 & 1 \\
\hline 5 & 8 & 2 & 4 \\
\hline$X$ & 6 & & \\
\hline$\Sigma$ & 30 & & 10 \\
\hline
\end{tabular}


Maka varians populasi dapat dihitung:

$\sigma^{2}=\frac{10}{5}=2$

\section{B. Jenis Varians}

Di atas telah disampaikan bahwa varians sebagai ukuran variasi dihitung dari populasi dan sampel, dengan menggunakan pendekatan (rumus) yang sedikit berbeda. Varians yang dihitung dari populasi disebut sebagai varians populasi (sebagai parameter), sedangkan ukuran yang diperoleh dari sampel disebut sebagai varians sampel (sebagai statistik).

Di samping itu, terdapat pula varians sistematis dan varians galat (error). Varians sistematis ialah variasi ukuran karena pengaruh-pengaruh tertentu yang diketahui atau tidak diketahui, yang membuat skor-skor cenderung ke suatu arah dan buka ke arah yang lain ${ }^{1}$. Sedangkan varians galat adalah fluktuasi atau variasi ukuran yang terjadi karena kebetulan. Varians galat merupakan varians acak. Terjadinya variasi ukuran macam ini adalah karena fluktuasi ukuran yang biasanya kecil dan kurang ajeg.

Salah satu jenis varians sistematik yang penting dalam penelitian adalah varians antar kelompok atau varians eksperimental. Varians antar kelompok atau varians eksperimental adalah varians yang mencerminkan perbedaan-perbedaan sistematis antar kelompok ukuran.

Penghitungan varians antar kelompok atau varians eksperimental dapat diperoleh melalui suatu kondisi eksperimen maupun dari suatu kondisi non eksperimen. Varians antar kelompok dihitung dengan menghitung besarnya rata-rata untuk tiap kelompok, yang selanjutnya dibandingkan dengan skor rata-rata untuk seluruh kelompok.

Misalkan peneliti bermaksud mengetahui efektivitas metode belajar tertentu terhadap hasil belajar, yang dilakukan dengan membandingkan keompok kontrol (Y) dan kelompok eksperimen (Z). Hasil pengujian dapat dilihat pada tabel di bawah ini.

\begin{tabular}{|l|l|l|}
\hline No. & Y & Z \\
\hline 1 & 4 & 5 \\
\hline 2 & 1 & 6 \\
\hline 3 & 2 & 3 \\
\hline 4 & 5 & 8 \\
\hline 5 & 6 & 7 \\
\hline$X$ & 3,6 & 5,8 \\
\hline$\Sigma$ & 18 & 29 \\
\hline
\end{tabular}

Rata-rata yang diperoleh selanjutnya dibandingkan dengan rata-rata untuk kedua kelompok tersebut, yang diperoleh skor sebesar 4,7 (hasil bagi 47 dibagi 10).

Selanjutnya skor tersebut didistribusi ke dalam tabel di bawah ini:

${ }^{1}$ Lihat Kerlinger p. 125 


\begin{tabular}{|l|l|l|l|}
\hline Kelompok & Rata-Rata & $\mathbf{x}$ & $\mathbf{X}^{\mathbf{2}}$ \\
\hline $\mathrm{Y}$ & 3,6 & $-1,1$ & 1,21 \\
\hline $\mathrm{Z}$ & 5,8 & 1,1 & 1,21 \\
\hline $\mathrm{X}$ & 4,7 & & \\
\hline$\Sigma \mathrm{x}^{2}$ & & & 2,42 \\
\hline
\end{tabular}

$\sigma b^{2}=\frac{2,42}{2}=1,21$

$\sigma^{2}$ menunjukkan suatu harga varians between (varians antar kelompok). Salah satu hal penting yang diperlukan untuk menghitung varians adalah varians total yang merupakan varians untuk keseluruhan anggota kelompok. Untuk menghitung varians total, seluruh skor dihitung secara bersama, lalu dihitung variansnya. Terhadap data di atas dapat dihitung varians total, yang dilakukan dengan cara:

\begin{tabular}{|l|l|l|l|}
\hline No. & $\mathbf{X}$ & $\mathbf{X}$ & $\mathbf{X}^{2}$ \\
\hline 1 & 4 & -0.7 & 0.49 \\
\hline 2 & 1 & -3.7 & 13.69 \\
\hline 3 & 2 & -2.7 & 7.29 \\
\hline 4 & 5 & 0.3 & 0.09 \\
\hline 5 & 6 & 1.3 & 1.69 \\
\hline 6 & 5 & 0.3 & 0.09 \\
\hline 7 & 6 & 1.3 & 1.69 \\
\hline 8 & 3 & -1.7 & 2.89 \\
\hline 9 & 8 & 3.3 & 10.89 \\
\hline 10 & 7 & 2.3 & 5.29 \\
\hline$X$ & 4,7 & & \\
\hline$\Sigma \mathrm{x}^{2}$ & & & 44.1 \\
\hline
\end{tabular}

Varians total dihitung:

$\sigma^{2}=\frac{44,1}{10}=4,41$

Apabila penghitungan varians dilakukan secara terpisah untuk masing-masing kelompok dan dihitung rata-ratanya maka diperoleh: 


\begin{tabular}{|l|l|l|l|l|l|l|}
\hline No. & $\mathbf{Y}$ & $\mathbf{X}$ & $\mathbf{X}^{\mathbf{2}}$ & $\mathbf{Z}$ & $\mathbf{X}^{\mathbf{2}}$ & $\mathbf{X}^{\mathbf{2}}$ \\
\hline 1 & 4 & 0.4 & 0.16 & 5 & -0.8 & 0.64 \\
\hline 2 & 1 & -2.6 & 6.76 & 6 & 0.2 & 0.04 \\
\hline 3 & 2 & -1.6 & 2.56 & 3 & -2.8 & 7.84 \\
\hline 4 & 5 & 1.4 & 1.96 & 8 & 2.2 & 4.84 \\
\hline 5 & 6 & 2.4 & 5.76 & 7 & 1.2 & 1.44 \\
\hline $\mathrm{X}$ & 3,6 & & & 5,8 & & \\
\hline$\Sigma \mathrm{X}^{2}$ & & & 17,2 & & & 14,8 \\
\hline
\end{tabular}

Varians untuk kedua kelompok dapat dihitung:

$\sigma y^{2}=\frac{17,2}{5}=3,44$ dan $\sigma z^{2}=\frac{14,8}{5}=2,96$ dengan rata-rata $=3,2$

Rata-rata dari kedua varians tersebut dinamakan varians dalam kelompok (within group variance). Apabila skor-skor yang diperoleh dimasukkan ke dalam rumus sederhana, yaitu:

$\sigma \mathrm{t}^{2}=\sigma \mathrm{b}^{2}+\sigma \mathrm{w}^{2}$; maka 4,41 =1,21 $+3,2$. Dengan demikian dapat disimpulkan bahwa varians total merupakan penjumlahan dari varians antara kelompok dengan varians dalam kelompok.

\section{Analisis Varians}

Analisis varians merupakan salah satu analisis untuk menguji perbedaan rata-rata untuk kelompok yang lebih dari dua. Seperti telah diketahui bersama bahwa untuk menguji perbedaan dua buah rata-rata dari sampel yang masing-masing diambil secara independen dilakukan dengan menggunakan uji $t$ ( $t$ test). Pengujian dengan uji t terbatas hanya untuk 2 buah rata-rata, sehingga apabila kita dihadapkan pada k buah rata-rata yang akan diuji $(\mathrm{k}>2)$, maka uji t sudah tidak bisa dipergunakan lagi. Salah satu cara yang dapat dipergunakan untuk menganalisis uji beda rata-rata untuk $\mathrm{k}$ buah rata-rata $(\mathrm{k}>2)$ adalah "one way analysis of variance" atau biasa dikenal dengan "ANOVA" (Bahasa Indonesia: Anava = Analisis Varians, yang selanjutnya istilah ini yang dipergunakan di sini). Secara sederhana penggunaan Anava didasarkan atas:

1. Ada $\mathrm{k}$ buah populasi $(\mathrm{k}>2)$

2. Rata-rata variat $\mathrm{X}$ untuk masing-masing populasi adalah; $\mu_{1}, \mu_{2}, \ldots . ., \mu_{\mathrm{k}}$

3. Hipotesis statistiknya adalah:

Ho : $\mu_{1}=\mu_{2}=\ldots=\mu_{\mathrm{k}}$

H1 : Sekurang-kurangnya ada Dua Buah $\mu$ yang tidak sama

4. Dari masing-masing populasi diambil sampal random berukuran $\mathrm{n}_{1}, \mathrm{n}_{2}, \ldots \mathrm{n}_{\mathrm{k}}$

5. Data Hasil Pengukuran variat $\mathrm{X}$ adalah 


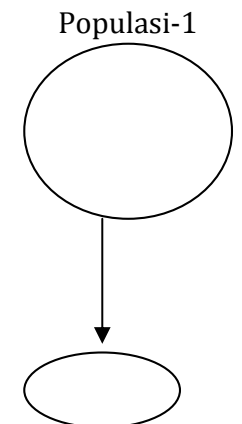

Sampel-1

$\mathrm{n}_{1}$

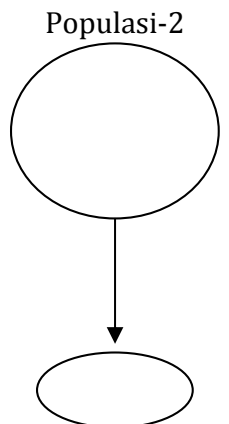

Sampel-2

$\mathrm{n}_{2}$

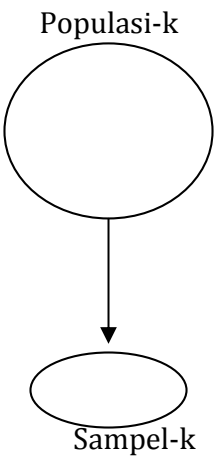

$\mathrm{n}_{\mathrm{k}}$

\begin{tabular}{|l|l|l|l|}
\hline 1 & 2 & $\bullet \bullet$ & $\mathrm{K}$ \\
\hline $\mathrm{x}_{11}$ & $\mathrm{x}_{12}$ & $\bullet \bullet$ & $\mathrm{x}_{1 \mathrm{k}}$ \\
\hline $\mathrm{x}_{21}$ & $\mathrm{x}_{22}$ & $\bullet \bullet$ & $\mathrm{x}_{2 \mathrm{k}}$ \\
\hline$\bullet$ & $\bullet$ & $\bullet$ & $\bullet$ \\
$\bullet$ & $\bullet$ & $\bullet$ & $\bullet$ \\
\hline $\mathrm{x}_{\mathrm{n} 11}$ & $\mathrm{x}_{\mathrm{n} 22}$ & $\bullet \bullet$ & $\mathrm{x}_{\mathrm{nkk}}$ \\
\hline $\mathrm{T}_{1}$ & $\mathrm{~T}_{2}$ & & $\mathrm{~T}_{\mathrm{k}}$ \\
\hline$\sum \mathrm{x}^{2} 11$ & $\sum \mathrm{x}_{12}$ & & $\sum \mathrm{x}^{2} 1 \mathrm{k}$ \\
\hline $\mathrm{x}_{1}$ & $\mathrm{x}_{2}$ & & $\mathrm{x}_{\mathrm{k}}$ \\
\hline $\mathrm{s}_{1}$ & $\mathrm{~s}_{2}$ & & $\mathrm{~S}_{\mathrm{k}}$ \\
\hline
\end{tabular}

6. Untuk menguji hipotesis:

Ho : $\mu_{1}=\mu_{2}=\ldots=\mu_{\mathrm{k}}$

H1 : Sekurang-kurangnya ada Dua Buah $\mu$ yang tidak sama

Digunakan Anava satu arah (One Way ANOVA)

Tabel ANAVA

\begin{tabular}{|l|l|l|l|l|}
\hline $\begin{array}{l}\text { SUMBER } \\
\text { VARIASI }\end{array}$ & $\begin{array}{l}\text { DEARAJAT } \\
\text { BEBAS (DB) }\end{array}$ & $\begin{array}{l}\text { JUMLAH } \\
\text { KUADRAT }(J K)\end{array}$ & $\begin{array}{l}\text { RATA-RATA } \\
\text { KUADRAT } \\
(\mathrm{RJK})\end{array}$ & UJI F \\
\hline $\begin{array}{l}\text { Antar } \\
\text { Kelompok }\end{array}$ & $\begin{array}{l}\mathrm{k}-1 \\
\left(\mathrm{db}_{\mathrm{k}}\right)\end{array}$ & $\mathrm{JK}_{\mathrm{k}}$ & $\mathrm{R}_{\mathrm{k}}=\mathrm{JK}_{\mathrm{k}} / \mathrm{DB}_{\mathrm{k}}$ & $\mathrm{F}=$ \\
\hline $\begin{array}{l}\text { Galat } \\
\text { (Residu) }\end{array}$ & $\begin{array}{l}\sum\left(\mathrm{n}_{\mathrm{j}}-\mathrm{k}\right) \\
\mathrm{DB}_{\mathrm{G}}\end{array}$ & $\mathrm{JK}_{\mathrm{G}}$ & $\mathrm{RK}_{\mathrm{G}}=\mathrm{JK}_{\mathrm{G}} / \mathrm{DB}_{\mathrm{G}}$ & $\mathrm{RK}_{\mathrm{K}} / \mathrm{RK}_{\mathrm{G}}$ \\
\hline Total & $\left(\sum \mathrm{n}_{\mathrm{j}}\right)-1$ & $\mathrm{JK}_{\mathrm{T}}$ & & \\
\hline
\end{tabular}




$$
C=\frac{\left(T_{1}+T_{2}+\ldots+T_{k}\right)^{2}}{\left(n_{1}+n_{2}+\ldots+n_{k}\right)}
$$

JKT = Jumlah Kuadrat untuk Total

$\left(\sum \mathrm{x} 2 \mathrm{i} 1+\sum \mathrm{x} 2 \mathrm{i} 2+\ldots+\sum \mathrm{x} 2 \mathrm{ik}\right)-\mathrm{C}$

JKK = Jumlah Kuadrat antar Kelompok

$\left(\frac{\mathrm{T}^{2}{ }_{1}}{\mathrm{n}_{1}}+\frac{\mathrm{T}^{2}{ }_{2}}{\mathrm{n}_{2}}+\ldots+\frac{\mathrm{T}^{2} \mathrm{k}}{\mathrm{n}_{\mathrm{k}}}\right)-\mathrm{C}$

$J K G=J u m l a h$ Kuadrat untuk Galat

$\mathrm{JKG}=\mathrm{JKT}-\mathrm{JKK}$

RKK $=$ Rata-rata kuadrat untuk antar kelompok

$\mathrm{RKK}=\mathrm{JKK} / \mathrm{DBK}$

RKG $=$ Rata-rata kuadrat untuk Galat

$\mathrm{RKG}=J K G / \mathrm{DBG}$

Titik Kritis Pengujian:

$\mathrm{F}\left(\alpha: \mathrm{DB}_{\mathrm{K}} ; \mathrm{DB}\right)$

7. Apabila Ho ditolak, maka pengujian dilanjutkan dengan membandingkan rata-rata setiap kelompok (Multiple Comparisons) guna melihat rata-rata kelompok mana yang berbeda secara statistik. Salah metode yang bisa dipergunakan adalah SCHEFFE'S METHOD
a. Hitung $s=\sqrt{(\mathrm{k}-1) \cdot \mathrm{F}\left(\boldsymbol{\alpha}: \mathrm{DB}_{\mathrm{k}} ; \mathrm{DB}_{\mathrm{G}}\right)}$
b. Hitung $\sigma=\sqrt{\left(\mathrm{RK}_{\mathrm{G}}\right)\left(\frac{1}{\mathrm{nj}}+\frac{1}{\mathrm{nj}^{\prime}}\right)}$
c. Hitung $\mathrm{s} \sigma$
d. Hitung setiap pasangan $\left|x j-x j^{\prime}\right|$
e. Apabila $\left|x j-x j^{\prime}\right| \geq s$. $\sigma$, maka kedua rata-rata itu secara statistik berbeda signifikan

Contoh Kasus:

Dugaan:

Ada perbedaan Tingkat Patuh Peraturan Lalu Lintas (TPPLL) antar Pengemudi Truk Antar Kota, Pengemudi Bus Antar Kota, Pengemudi Mobil Pribadi dan Pengemudi Kendaraan Angkutan Kota.

Data:

TPPLL diukur oleh instrumen pengukuran yang dapat memberikan skor numerik yang memenuhi skala pengukuran interval. 
TABEL HASIL PENGUKURAN TPPLL

\begin{tabular}{|l|l|l|l|}
\hline $\begin{array}{l}\text { TRUK ANTAR } \\
\text { KOTA }\end{array}$ & $\begin{array}{l}\text { BUS ANTAR } \\
\text { KOTA }\end{array}$ & $\begin{array}{l}\text { KENDARAN } \\
\text { PRIBADI }\end{array}$ & ANGKUTAN KOTA \\
\hline 86 & 88 & 104 & 75 \\
\hline 94 & 87 & 103 & 79 \\
\hline 97 & 78 & 94 & 78 \\
\hline 92 & 80 & 96 & 74 \\
\hline 92 & 81 & 99 & 72 \\
\hline 99 & 80 & 98 & 78 \\
\hline 94 & 85 & 97 & 77 \\
\hline 95 & 88 & & 82 \\
\hline 93 & 86 & & \\
\hline & 81 & & \\
\hline
\end{tabular}

Menurut pendapat para peneliti di bidang hukum, sekalipun TPPLL para pengemudi itu berbeda, tetapi variasi kepatuhan terhadap TPPLL antar kelompok adalah sama.

Pengujian

1. Tinggi rendahnya TPPLL diperlihatkan oleh Nilai numerik rata-rata skor TPPLL.

Hipotesis Statistik:

Ho : $\mu_{1}=\mu_{2}=\ldots .=\mu_{\mathrm{k}}$

H1 : Sekurang-kurangnya ada Dua Buah $\mu$ yang tidak sama

2. $\alpha=0,05$

3. Data seperti pada tabel di atas

4. Perhitungan:

\begin{tabular}{|l|l|l|l|l|l|}
\hline \multirow{2}{*}{ Statistik } & Kelompok & \multirow{4}{|l|}{ Jumlah } \\
\cline { 2 - 5 } & 1 & 2 & 3 & 4 & \\
\hline $\mathrm{nj}$ & 9 & 10 & 7 & 8 & 34 \\
\hline $\mathrm{Tj}$ & 842 & 834 & 691 & 615 & 2982 \\
\hline$\sum \mathrm{xij}^{2}$ & 78880 & 69684 & 68291 & 47347 & 264202 \\
\hline $\mathrm{xj}$ & 93,55556 & 83,4 & 98,71429 & 76,875 & \\
\hline $\mathrm{sj}$ & 3,64387 & 3,77712 & 3,63842 & 3,13676 & \\
\hline
\end{tabular}

$$
\begin{aligned}
\mathrm{C} & =\frac{(842+834+691+615)^{2}}{(9+10+7+8)}=261538,9412 \\
\mathrm{JKT} & =(78880+69684+68291+47347)-261538,9412 \\
& =2663,05883 \\
\mathrm{JKK} & =\left(\frac{842^{2}}{9}+\frac{834^{2}}{10}+\frac{691^{2}}{7}+\frac{615^{2}}{8}\right)-261538,9412
\end{aligned}
$$


$=2280,13303$

$J K G=2663,05883-2280,13303=382,92580$

$\mathrm{RKK}=2280,13303 / 3=760,0443433$

$\mathrm{RKG}=382,92580 / 30=12,76419333$

$\mathrm{F}=760,0443433 / 12,76419333=59,54503537$

5. Daerah dan titik kritis

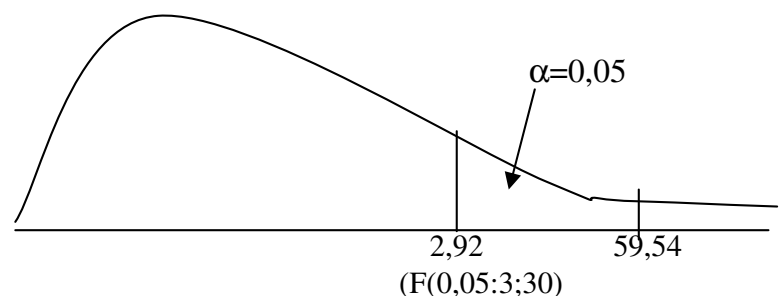

Hasil Pengujian menunjukkan bahwa Ho ditolak, sehingga selanjutnya harus dilakukan analisis dengan Metode Scheffe's

Untuk Membandingkan kelompok 1 dengan kelompok 2

a. $s=\sqrt{3 \times 2,92}=2,95972971738975$

b. $\sigma=\sqrt{(12,76419333)\left(\frac{1}{9}+\frac{1}{10}\right)}=1,6415428828798$

c. $\mathrm{s} \times \sigma=4,85852325282899$

d. $|x 1-x 2|=10,155556$

e. $|\mathrm{x} 1-\mathrm{x} 2| \geq \mathrm{s}$ x $\sigma$; perbedaan kelompok 1 dengan kelompok 2 signifikan

Demikian pula langkah pengujian untuk kelompok selanjutnya. Salah satu hal penting dalam metodologi adalah penentuan populasi dan sampel penelitian. Pengambilan sampel dalam penelitian sangat menentukan kredibilitas penelitian yang dilakukan. Oleh karena itu penentuan sampel harus memenuhi unsur-unsur keterwakilan. Hal ini dimaksudkan agar sampel yang diperoleh benar-benar mewakili seluruh karakteristik yang dimiliki oleh populasi.

Teknik sampling sangat ditentukan oleh variasi populasi. Untuk populasi yang homogen, simpel random sampling dan sistematik sampling dapat dilakukan, sedangkan untuk populasi yang heterogen teknik sampling yang dipergunakan adalah cluster dan stratified random sampling atau gabungan dari keduanya.

Ukuran sampel yang diinginkan oleh peneliti sangat ditentukan oleh besarnya populasi, hasil ujicoba, dan teknik analisis yang dipergunakan. Salah satu ukuran yang dipergunakan untuk mengukur keberagaman data dalam penelitian dilakukan dengan menghitung varians. Varians memiliki makna yang sama pentingnya dengan rata-rata pada penghitungan ukuran gejala pusat. Salah satu pengembangan dari penghitungan varians adalah analisis varians. Analisis ini dipergunakan sebagai teknik analisis untuk menguji 
perbedaan rata-rata apabila yang diuji tersebut lebih dari dua kelompok. Analisis ini juga menghendaki analisis uji beda lanjut apabila diketahui hasil analisis varians menunjukkan hasil yang signifikan. 


\section{BAB VI \\ SURVEI CEPAT \\ (QUICK ASSESSMENT)}

\section{A. SEJARAH}

Survei cepat pertama kali dikembangkan pada proyek Expanded Programme on Immunization- WHO. Setelah itu berkembang antara lain pengembangan perangkat lunak Csurvey oleh Ariawan dan Frerichs (1994) untuk merancang sampel. Pada tahun yang sama CDC mengembangkan CSAMPLE software untuk analisis data survey cepat.

Di Indonesia Survey cepat sudah diuji beberapa kali antara lain:

- Uji coba di Bogor oleh Riono dan Irawan menunjukkan pengumpulan informasi pemeriksaan kehamilan dapat diperoleh dalam waktu 2 minggu

- FKM-UI juga membuktikan bahwa metoda Survey cepat dapat diterapkan di kabupaten

\section{B. KARAKTERISTIK}

Ada beberapa karakteristik kapan kita akan menggunakan survei cepat ini, antara lain :

- Digunakan untuk mengukur kejadian yang sering terjadi di masyarakat

- Pengambilan Sampel 2 tahap, 30 klaster dan masing-masing cluster biasanya 7-10 sampel/responden

- Jumlah pertanyaan dibatasi maksimal 20

- Waktu sejak pelaksanaan sampai pelaporan singkat sekitar 3 minggu

- Analisis dilakukan dengan alat statistik sederhana dengan tetap memperhatikan kaidah statistik yang berlaku

\section{LANGKAH-LANGKAH}

- Menentukan masalah kesehatan yang akan dipelajari serta tujuan pelaksanaan survei secara jelas dan terinci

- Menentukan besar sampel dan metoda sampling

- Mengembangkan instrumen pengumpul data, susun, uji coba, perbaiki

- Pengorganisasian dan pelaksanaan survey, rencanakan dengan rinci, termasuk jumlah pewawancara yang dibutuhkan, pastikan tenaga ini mengerti tentang tata cara pemilihan responden, semua pertanyaan dan teknik dasar wawancara

- Pengolahan data, analisis, dengan komputer 


\section{ALASAN PENGGUNAAAN SAMPEL DALAM POPULASI}

Ada beberapa alasan kenapa harus menggunakan survei cepat ini jika dibandingkan dengan survei konvensional, antara lain “

- Besarnya populasi

Semakin besar populasi, maka tingkat kesulitan mengambil sampel juga akan semakin besar karena akan semakin beragam karakteristik populasi yang akan kita teliti

- Keterbatasan dana

Survei konsvensional menggunakan sampel yang lebih besar jika dibandingkan dengan suvei cepat. Sampel yang besar akan berkorelasi dengan besarnya dana yang akan digunakan untuk survei

- Keterbatasan tenaga

- Keterbatasan Waktu

\section{E. BESAR SAMPLE}

Teknik sampling yang sering digunakan dalam survei cepat ini adalah :

1. Simple Random Sampling atau sampel acak sederhana

2. Klaster Random Sampling atau sample acak dengan klaster.

\section{RUMUS MENGHITUNG BESAR SAMPEL ACAK SEDERHANA}

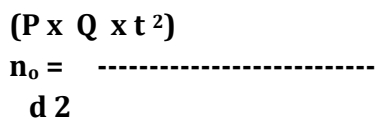

Kemudian disesuaikan dengan besar populasi

$$
\mathbf{n}_{\text {sample }}=\mathbf{n}_{\mathrm{o}} /\left(\mathbf{1}+\left(\mathbf{n}_{\mathrm{o}} / \mathrm{N}\right)\right)
$$

Jika Prevalensi belum diketahui

Prevalensi $\rightarrow \mathrm{P}=50 \%(0,50) \quad \mathrm{Q}=(1-\mathrm{P})=0,5 \quad \mathrm{PQ}=0,5 \times 0,5=0,25$

$\mathrm{t}=2 \quad \mathrm{t}^{2}=2^{2}=4$

$\mathrm{d}=$ selisih yang diharapkan antara prevalensi sampel dan prevalensi populasi $(1 \%, 2 \%$, $3 \%, 4 \%, 5 \%)$.

Besar sampel (sebelum disesuaikan dengan besar Populasi) $=\mathbf{n}_{\mathbf{o}}$

$\mathrm{d}=1 \% \rightarrow \mathrm{n}_{\mathrm{o}}=10000$

$\mathrm{d}=2 \% \rightarrow \mathrm{n}_{\mathrm{o}}=2500$

$\mathrm{d}=3 \% \rightarrow \mathrm{n}_{\mathrm{o}}=1111$

$\mathrm{d}=4 \% \rightarrow \mathrm{n}_{0}=625$

$\mathrm{d}=5 \% \rightarrow \mathrm{n}_{\mathrm{o}}=400$

masuk dalam rumus : $\mathrm{n}_{\text {sampel }}=\mathrm{n}_{\mathrm{o}} /\left(1+\left(\mathrm{n}_{\mathrm{o}} / \mathrm{N}\right)\right)$ 
Dan selanjutnya besar sampel dengan acak sederhana diperoleh :

\begin{tabular}{|c|c|c|c|c|c|}
\hline Besar & \multicolumn{5}{|c|}{$\mathrm{d}=(\mathrm{p}-\mathrm{P})$} \\
\hline Populasi=N & $\mathrm{d}=1 \%$ & $\mathrm{~d}=2 \%$ & $\mathrm{~d}=3 \%$ & $\mathrm{~d}=4 \%$ & $\mathrm{~d}=5 \%$ \\
\hline$<100$ & semua & semua & semua & semua & semua \\
\hline 100 & 99 & 96 & 92 & 86 & 80 \\
\hline 200 & 196 & 185 & 169 & 152 & 133 \\
\hline 300 & 291 & 268 & 236 & 203 & 171 \\
\hline 400 & 385 & 345 & 294 & 244 & 200 \\
\hline 500 & 476 & 345 & 345 & 278 & 222 \\
\hline 600 & 566 & 484 & 390 & 306 & 240 \\
\hline 700 & 654 & 547 & 429 & 330 & 255 \\
\hline 800 & 741 & 606 & 465 & 351 & 267 \\
\hline 900 & 826 & 662 & 497 & 369 & 277 \\
\hline 1000 & 909 & 714 & 526 & 385 & 286 \\
\hline 1200 & 1071 & 811 & 577 & 411 & 300 \\
\hline 1400 & 1228 & 897 & 619 & 432 & 311 \\
\hline
\end{tabular}

\section{RUMUS MENGHITUNG BESAR SAMPEL ACAK DENGAN KLASTER}

\section{JUMLAH SAMPEL}

- Ada 2 tahap pemilihan pertama memilih klaster dan kedua memilih subyek dalam klaster

- $\quad \mathrm{N}$ sampel klaster $=\mathrm{N}$ sampel acak sederhana $\mathrm{X}$ disain effek.

- $\quad$ Disain efek = Varian disain klaster/ varian disain acak sederhana

- Asumsi yang digunakan ada keragaman antar klaster tapi dalam klaster heterogen

- Secara mudah jumlah sampel untuk survey kasus yang tinggi (prevalensi antara $15 \%-85 \%$ ) adalah 30 klaster X 7 subyek (tiap klaster)= 210 subyek.

\section{SAMPLING}

Survey cepat biasa menggunakan 30 klaster bila prevalensi yang akan disurvey antara $15 \%-85 \%$, maka sampel tiap klaster 7 orang.

Besar sampel pada survey dengan menggunakan disain klaster :

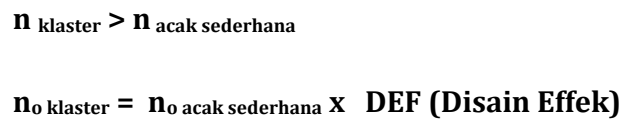

- nilai DEF dari 1 sampai 4 
- $P+Q=1 \quad P=$ Prevalensi pada populasi

Besar sampel untuk pengambilan sampel dengan klaster (sebelum disesuaikan dengan besar Populasi) = n0-klaster

$$
\begin{aligned}
& d=1 \% \rightarrow \text { n0-klaster }=10000 \times 2=20000 \\
& d=2 \% \rightarrow \text { n0-klaster }=2500 \times 2=5000 \\
& d=3 \% \rightarrow \text { n0-klaster }=1111 \times 2=2222 \\
& d=4 \% \rightarrow \text { n0-klaster }=625 \times 2=1250 \\
& d=5 \% \rightarrow \text { n0-klaster }=400 \times 2=800
\end{aligned}
$$

Dan selanjutnya masukan rumus

$\mathbf{n}_{\text {sample }}=\mathbf{n}_{\mathrm{o}} /\left(\mathbf{1}+\left(\mathrm{n}_{\mathrm{o}} / \mathrm{N}\right)\right)$

\section{Besar Sampel untuk Sampling Klaster}

\begin{tabular}{|c|c|c|c|c|c|}
\hline Besar & \multicolumn{5}{|c|}{$\mathrm{d}=(\mathrm{p}-\mathrm{P})$} \\
\hline Populasi=N & $\mathrm{d}=1 \%$ & $\mathrm{~d}=2 \%$ & $\mathrm{~d}=3 \%$ & $\mathrm{~d}=4 \%$ & $\mathrm{~d}=5 \%$ \\
\hline$<100$ & semua & semua & semua & semua & semua \\
\hline 100 & 100 & 98 & 96 & 93 & 89 \\
\hline 200 & 198 & 192 & 183 & 172 & 160 \\
\hline 300 & 296 & 283 & 264 & 242 & 218 \\
\hline 400 & 392 & 370 & 339 & 303 & 267 \\
\hline 500 & 488 & 455 & 408 & 357 & 308 \\
\hline 600 & 583 & 536 & 472 & 405 & 343 \\
\hline 700 & 676 & 614 & 532 & 449 & 373 \\
\hline 800 & 769 & 690 & 588 & 488 & 400 \\
\hline 900 & 861 & 763 & 641 & 523 & 424 \\
\hline 1000 & 952 & 833 & 690 & 556 & 444 \\
\hline 1200 & 1132 & 968 & 779 & 612 & 480 \\
\hline 1400 & 1308 & 1094 & 859 & 660 & 509 \\
\hline
\end{tabular}

Penentuan klaster dengan PPS menurut jumlah populasi (subyek yang akan diteliti), bumil, balita, anak usia sekolah, WUS dll.

\section{F. CONTOH SURVEI CEPAT KABUPATEN}

- Sebaiknya memberikan gambaran kecamatan

- Setiap kecamatan dipilih 30 klaster yang tersebar diseluruh desa (bila desa $<30$ buah) dengan proportional to size (PPS) dari subyek penelitian 


\begin{tabular}{|l|l|l|}
\hline Desa & umlah populasi & umlah klaster \\
\hline Kejaksan & 225 & 4 \\
\hline Kanggraksan & 200 & 4 \\
\hline Kesenden & 320 & 6 \\
\hline Arjawinangun & 400 & 8 \\
\hline Buntet & 175 & 3 \\
\hline Kapetakan & 250 & 5 \\
\hline Jumlah & 1530 & 30 \\
\hline \hline
\end{tabular}

Tiap 1530/30 klaster $=51$ subyek $/$ klaster

\section{G. PEMILIHAN SAMPEL DALAM KLASTER}

Setelah klaster terpilih secara acak, maka tahap selanjutnya adalah memilih 7 s.d 10 responden pada tiap klaster (3 responden sebagai cadangan). Secara ideal pemilihan sampel di tingkat klaster adalah menggunakan metode acak sederhana, ini artinya harus mempunyai kerangka sampel pada tiap klaster, kemudian dipilih 7 s.d 10 responden secara acak sederhana tiap klaster. Tetapi cara ini tidak praktis karena untuk membuat kerangka tersebut bukan hal yang mudah.

Cara yang telah diuji cobakan dan sering dilakukan adalah dengan cara sebagai berikut:

1. 1. Di klaster yang terpilih, pengumpul data mendatangi pusat klaster (biasanya pusat klaster atau pusat desa adalah balai desa, alun-alun, ataupun pusat kegiatan lainnya).

2. Di tengah klaster tersebut, pewawancara berjalan dengan memilih arah (yang dipilih secara acak bisa dipilih salah satu, ke kiri, ke kanan, ke depan atau kebelakang, cara paling mudah adalah dengan lempar koin untuk memilih arah jalan secara acak). Kemudian pewawancara berjalan sesuai arah sampai batas klaster.

3. Sambil berjalan, pewawancara menggambar peta mengenai rumah-rumah yang ada di kiri dan kanan jalan yang dilewati, apabila pada saat pemetaan, pewawancara melewati persimpangan jalan sebelum mencapai batas klaster, pewawancara dapat menggunakan koin lagi untuk menentukan arah, sehingga apabila telah selesai dibuat pemetaan hasilnya.

4. Setelah selesai melakukan pemetaan, maka rumah-rumah tersebut diberi nomor, kemudian secara acak pewawancara mendatangi rumah pertama untuk dilakukan wawancara. Pengambilan sampel secara acak ini bisa dengan cara diundi atau menggunakan tabel bilangan acak (pada komputer ada fasilitas tabel bilangan acak). 
5. Bila rumah pertama yang dipilih secara acak memenuhi syarat sebagai sampel, artinya dalam rumah tersebut terdapat responden yang sesuai dengan kriteria sampel, maka wawancara dapat dilakukan, apabila tidak memenuhi syarat maka pindah ke rumah berikutnya.

6. Rumah berikutnya yang didatangi adalah rumah terdekat dari rumah sebelumnya, akan tetapi lebih baik bila rumah berikutnya tersebut juga diambil secara acak. Ada banyak cara untuk menentukan rumah berikutnya tersebut, misalnya mencari rumah berikutnya diambil rumah pertama terdekat, cara lain adalah mendatangi rumah berikut dengan jarak 3 rumah atau jarak 5 rumah yang terdekat dari rumah yang telah didatangi, cara lain misalnya hasil pemetaan dibagi menjadi 4 titik bagian dan masing-masing titik bagian diambil 2 responden.

7. Pada satu klaster, pencarian responden akan berakhir apabila sudah menemukan paling sedikit 7 responden (Sebaiknya tiap klaster, jumlah responden dibuat sama yaitu minimal 7 responden dan maksirnal 10 responden).

\section{H. PENGOLAHAN DAN ANALISIS DATA}

Apabila data sudah terkumpul maka tahap berikutnya adalah melakukan pengolahan data, dan dapat dilakukan dengan bantuan komputer, agar hasilnya bisa lebih cepat dan akurat. Proses pengolahan data mulai memasukkan data, membersihkan, mengkode jawaban harus dilakukan sesuai kriteria agar tidak ada kesalahan pada saat analisis nanti. Apabila pengolahan data selesai kemudian dilakukan analisis data menggunakan tehnik statistik yang sesuai dengan tujuan survai. Analisis yang digunakan pada survai cepat ini pada umumnya bersifat sederhana misalnya menghitung proporsi, mean, simpangan baku maupun tampilan data berupa tabel atau grafik sederhana.

\section{LAPORAN BERISI}

1. Judul, penulis, waktu survei, kata pengantar,daftar isi

2. Abstrak yang berisi temuan utama dan implikasinya

3. Justifikasi, latar belakang dan masalah yang diteliti

4. Tujuan survei

5. Metodologi: berisi lokasi, indikator utama yang diukur, populasi, sampel, alat ukur, prosedur analisis,

6. Hasil berisi deskriftif singkat temuan survei, tabel dan grafik

7. Diskusi berisi interpretasi hasil serta implikasinya terhadap program gizi dimasa datang

8. Kesimpulan berisi ringkasan temuan penting

9. Saran rekomendasi bagi perencana dan pelaksana program

10. Daftar pustaka, berisi daftar bacaan yang digunakan menyusun laporan survey

11. Lampiran daftar pertanyaan atau instrumen yang digunakan 


\section{DAFTAR PUSTAKA}

Sugiarto, dkk. 2001. Teknik Sampling. Penerbit PT Gramedia Pustaka Utama. Jakarta

Purwanto, J. 2003. Dasar-dasar Metode Penarikan Sampel. Sekolah Tinggi Ilmu Statistik. Jakarta.

Ary, Donal, Lucy Cheser Jacobs dan Ashgar Razavieh, (1982), Pengantar Penelitian dalam

Pendidikan, diterjemahkan oleh Arief Furchan, Surabaya: Usaha Nasional.

Bungin, Burhan, (2005), Metodologi Penelitian Kuantitatif, Jakarta: Kencana

Fraenkel, Jack R. and Norman E. Wallen, (1993), How to Design and Evaluate Research in Education, Singapore: McGraw-Hill.

Furqon, (1997), Statistika Terapan untuk Penelitian, Bandung: Alfabeta

Kerlinger, (2004), Asas-Asas Penelitian Behavioral (diterjemahkan oleh Landung R.

Simatupang), Yogyakarta: Gadjah Mada University Press.

Machin, D., \& Campbell, M.J., (1989), Statistical Tables for The Design of Clinical Trials, London: Blackwell Scientific Publication.

Singarimbun, Masri dan Sofyan Efendi (Editor), (1989), Metode Penelitian Survai, Jakarta: LP3ES.

Slamet, Y, (1993), Analisis Kuantitatif untuk Data Sosial, Solo: Dabara Publisher

Sudjana, (1992), Metoda Statistika, Bandung: Tarsito

Sudjana, Nana dan R. Ibrahim, (2004), Penelitian dan Penilaian Pendidikan, Bandung: Sinar Baru Algensindo.

Sukmadinata, Nana Syaodih, (2005), Metode Penelitian Pendidikan, Bandung: Kerjasama PPs Universitas Pendidikan Indonesia dengan Remaja Rosda Karya.

Surachmad, Winarno, (1998), Pengantar Penelitian Ilmiah; dasar, metode, dan teknik, Bandung: Tarsito.

Suryabrata, Sumadi, (2004), Metodologi Penelitian, Jakarta: Radja Grafindo Persada.

Walpole, Ronald E. (1983), Introduction to Statistics, New York: Macmillan Publishing 


\section{PROFIL PENULIS}

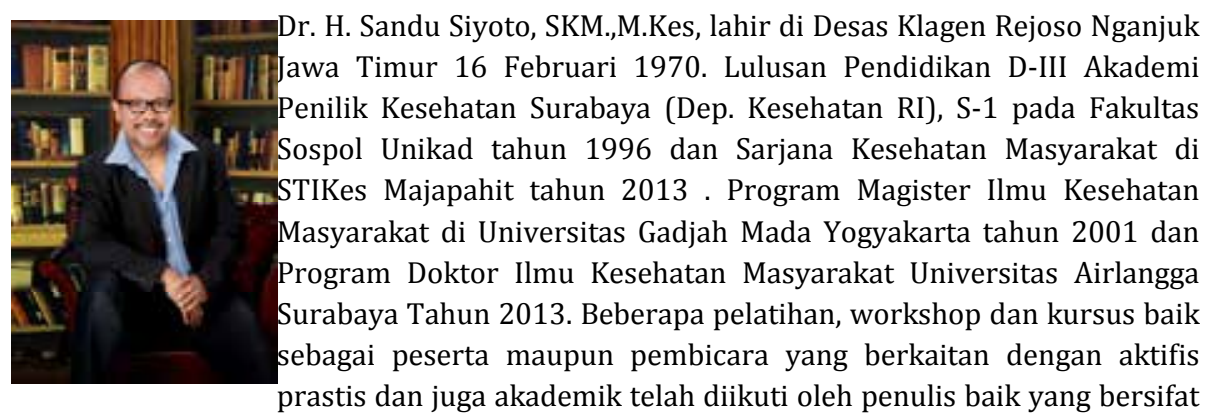

lokal, regional, nasional serta Internasional (Singapura, Johor Malaysia, Melbourne, Hobart Tasmania,Taiwan, Philipina).

Beberapa hasil penelitian penulis sudah dipublikasikan dalam forum regional, nasional bahkan internasional. Selain itu beberapa buku dan karya penulis juga telah diterbitkan, diantaranya "Kesehatan Reproduksi " (2013) yang ditulis bersama Dr. Hasdiana, M.Kes, "Kledek Nganjuk" (2014) yang ditulis bersama budayawan Dr. Purwadi, SS.,M.Hum, "Dasardasar Riset Keperawatan" ditulis bersama Dr. Hasdianah Hasan Rohan, M.Si, Dr. Indasah, M.Kes, "Dasar Metodologi Penelitian " (2015) yang ditulis bersama M. Ali Sodik, M.A., "Dasar Statistik untuk Kesehatan” (2016) yang ditulis bersama Ratna Wardani, S.Si, MM

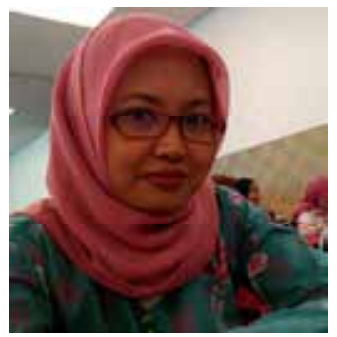

Nia Sari., SSi. MKes adalah Staf Pengajar Biostatistika dan Kependudukan di Program Studi Ilmu Kesehatan Masyarakat STIKES Surya Mitra Husada Kediri sejak tahun 2004. Ia memperoleh gelar Sarjana pada jurusan Statistika Universitas Brawijaya (2003), program Magister Kesehatan di Universitas Negeri Sebelas Maret (2008). Dan, saat ini sedang menempuh Program Doktor di bagian Biostatistika dan Kependudukan Universitas Airlangga. 


\section{APLIKASI DAN TEKNIK SURVEY BIDANG KESEHATAN}

Literasi Media Publishing

literasimedia01@gmail.com

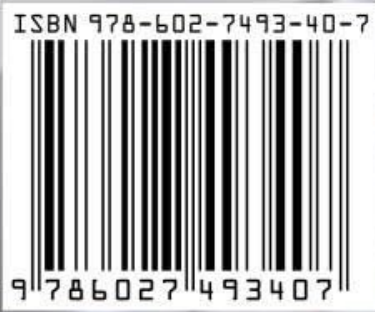

